\title{
横軸方向周波数応答実験による両眼転導ビジュアルサーボの評価
}

\author{
田 宏志 ${ }^{* 1}$ ，寇 ギョウ郡*1，見浪 護*2
}

\section{Evaluation of eye-vergence visual servoing by lateral frequency response}

\author{
Hongzhi TIAN ${ }^{* 1}$, Yejun KOU*1 and Mamoru MINAMI*2 \\ ${ }^{*}{ }_{1,2}$ Division of Mechanical and Systems Engineering, Graduate school of Natural Science and Technology, Okayama University \\ 3-1-1 Tsushima-naka, Kita-ku, Okayama 700-8530, Japan
}

Received: 21 April 2017; Revised: 11 November 2017; Accepted: 25 December 2017

\begin{abstract}
Visual servoing towards moving target with hand-eye cameras fixed at a hand of a robot is inevitably affected by the hand's dynamical oscillations, therefore it is difficult to keep target's position always at the center of camera's view, because nonlinear dynamical effects of whole manipulator stand against tracking ability of the visual servoing. One possible solution to overcome this problem is that the visual servoing control of the hand and eye-vergence is separated independently, so that the camera can track the target to observe it at the center of camera images to enhance the tracking ability (trackability). In line with this tactics, the authors have developed an eye-vergence visual servoing control system to enhance the trackability. With several experiments, it has been shown that the trackability of the eye-vergence motion is superior to the one of hand-eye system since the eyes' motion can be quicker than the hand's motion.
\end{abstract}

Keywords : Visual servoing, Eye-vergence, Lateral frequency response, Quaternion

\section{1. 緒言}

ロボットビジョンの分野では,ビジュアルサーボと呼ばれる制御方法が注目されている (Allen et al., 1993, Hutchinson et al., 1996, Malis et al., 1999, Oh and Allen, 2001).ビジュアルサーボとは , 視覚センサから得られる視覚情報を フィードバックループに組み込むことでロボットの動作を制御する方法であり，常に変化する環境や未知の環境で 働くロボットへの適用か期待されている . 具体的な手法は , 位置ベース制御 (Sepp et al., 2006)，イメージベース制 御 (Hiramatsu et al., 2009, Tahri et al., 2009, Tahri and Chaumette, 2005) とハイブリッド視覚サーボイング (Massoud Farahmand et al., 2009, Kim et al, 2009)の3つに大別される . ビジュアルサーボの認識能力を向上させるために , 八 ンドアイ構成をとる方法 (松浦，丸，2011, Kim et al, 2009, Shiozaki and Murakami, 2006)，ステレオカメラを使用 する方法 (Brandou et al, 2006, Song et al., 2007) と複数のカメラを使用する方法 (Stavnitzky and Capson, 2000) , ま たは二台のカメラのうち一台のカメラを手先に固定し，もう一台を空間に固定する方法 (Dune et al., 2007) が提案 されている .これらの方法はカメラの数を増やすことて環境を認識する視点の数を増加させている .

人が動く目標を視認し追従し続ける場合, 対象物の移動速度が遅い時は, 頭の向きや上半身のねじりを使って 対象物を顔の正面で認識し目標を追従できる．しかし対象物の移動速度が速くて顔を目標に向けることができな い場合は，眼球の運動を用いて目標を視野内に保持し視認し続ける行動をとることができる .さらに両眼は同じ 対象物を眼球に映る画像の中央に写像させるように共調して運動 (両眼転導 , Eye-vergence) することが知られてい

\footnotetext{
No.17-00182 [DOI:10.1299/transjsme.17-00182], J-STAGE Advance Publication date : 11 January, 2018

${ }^{* 1}$ 岡山大学 大学院自然科学研究科（干700-8530 岡山県岡山市北区津島中 3-1-1）

$*_{2}$ 正員, 岡山大学 大学院自然科学研究科

E-mail of corresponding author: psnc8ytd@s.okayama-u.ac.jp
} 

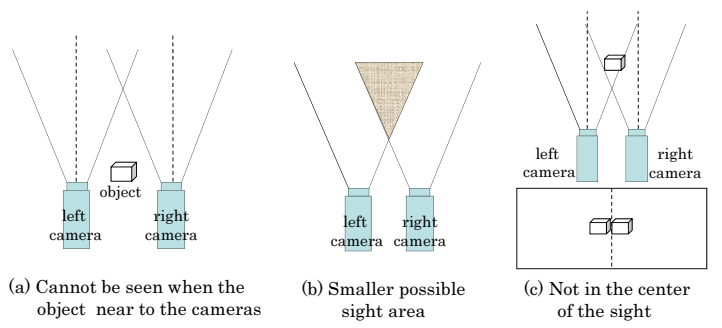

Fig. 1 Disadvantage of Fixed Camera System
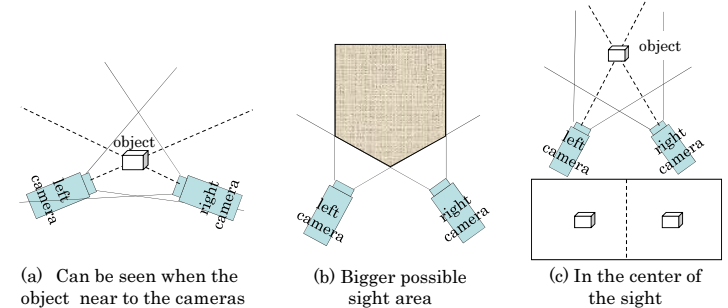

Fig. 2 Advantage of Eye-vergence System

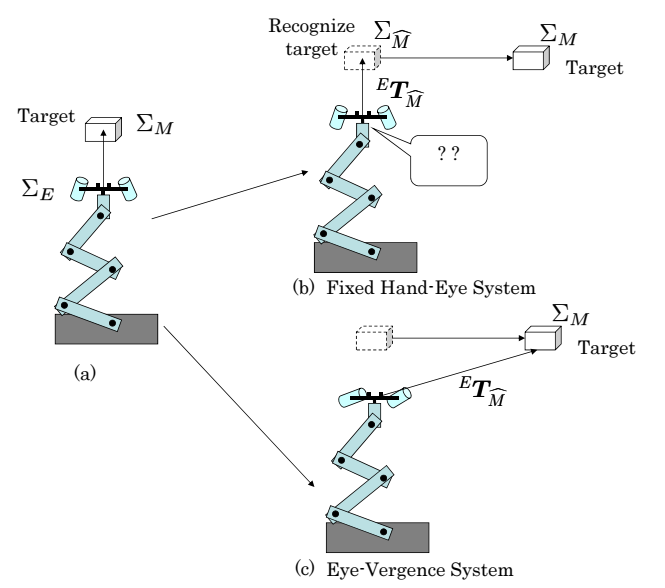

Fig. 3 Dynamical Advantage of Eye-Vergence System

る.光こで著者の一人は視線方向を制御する Eye-Vergence コントロールシステムを提案 (Song et al., 2011) し，安 定性について議論した .

Eye-Vergence システムは運動学と動力学についての利点があり，まず運動学について述べる . カメラがハンド 部に固定されている固定ハンドアイシステムは, 対象物がカメラに近いとき対象物を認識できない場合がある (図 1 (a))，また二つのカメラの共通可視領域か狭く(図 1 (b))，さらに可視領域内の対象物であっても図 1(c) に示すよ うにカメラ画像視野の中心に写像されることはない .このことは,レンズ周辺部で大きくなるレンズのひずみの 影響を受けやすく収差の問題を生じる. 以上より固定ハンドアイシステムは位置／姿勢計測が不正確になる場合や， 不可能になる場合があるという本質的な問題を持っていることが分かる .この問題を解決するため，本論文では 画像の中心で対象物を捉えるためにカメラ自身の姿勢を変化させる自由度を与える . カメラの姿勢を変えること が可能になるので, 図 2 の (a)-(c) に示すように, 対象物をよりよく観測することができる . 図 2 の (a)-(c) は図 1 の問題点 (a)-(c) に対応した Eye-Vergence システムの利点を示している . (a) , (b) は両眼可視領域が拡大すること， (c) はレンズの中心で対象物を観測することによってレンズ収差により発生する入力画像のひずみを避けられるこ とを示している .

\section{2. 従来研究との比較と 本報の新規性}

ビジュアルサーボの研究には, 対象物を認識し一定の距離を維持しつつ追従する研究が多い (Tahri and Chaumette, 2005) が， これでは対象物を把持するなどのタスクを達成することはできない . 本報では, ビジュアルサーボの目 
的は手先を対象物に近づけて掴むなどの動作をすることと考えることにする .この時 , 手先と対象物の間の関係は 時変であり，接近する対象物を認識し続けるためには Eye-Vergence 機能が必要である . 図 2 に示す Eye-Vergence システムでは, カメラ中央で対象物を撮像する視線方向制御が可能であるため. カメラは対象物を視野中央で注 視し続けることができる (Minami and Song, 2009, Song et al., 2011, Song and Minami, 2009) .

ビジュアルサーボの応用では, 認識対象物がカメラ視野内に留まるように安定に保つ必要がある . 図 3(a) は, カ メラが対象物を捉え続けることができる状態を示す . (b) に示すロボットのカメラはハンド部に固定されており， 対象物が速く動くと対象物はカメラの視界から消失し，制御系が暴走するという危険な状態に陥る可能性がある ことを示している.よって，ビジュアルサーボシステムにおいては，カメラが動く対象物をカメラ視野内にとらえ つづける能力である可追跡性を高めることが重要である . また , カメラの質量と慣性モーメントがマニピュレータ 全体より相対的に小さいので, 固定ハンドアイシステムより Eye-Vergence システムの方が追従特性が良いと考え られる . 図 3(c) に示すように，カメラ視線制御をハンド部制御に追加することで，対象物を追跡する能力を高め ることができる . カメラの視界内に対象物を撮像し続ける性能に関する考察は Chesi ら (Chesi et al., 2004)によっ て研究されているが, Eye-vergenceにより追従特性を改善することは, この問題の解決への一つのアプローチと考 えることができる．

高速ビジョンを用いて石川らが開発したダイナミックリグラスピングは二つのパンチルトカメラを用いて対象 物の位置/姿勢 (5DoF) を認識して追従できる (Furukawa et al., 2006) . 一方で石川らが開発したサッカードミラー (Saccade Mirror) 高速視線制御システムは, ガルバノミラーで光の伝搬経路を変える高速な視線の制御を行うこと ができ (奥村他，2013)，素早い追跡性を達成した．しかしながら，产のシステムは対象物の姿勢に対するビジュア ルサーボは行われておらず, 対象物の姿勢に依存したロボットハンドの把持姿勢を制御する必要がある場合は問 題となる .

著者らの従来の研究では, ハンドアイ固定カメラ構成のロボットに対して, ハンドアイロボットの速度/角速 度が画像内の対象物の移動速度に与える影響を実時間遺伝的認識法 (1-step GA (Song et al., 2007, Minami and Song, 2009)) に組み込んだフィードワード補償を付加することでサーボ特性が改善されることを示した (宋, 見浪, 2010, 宋他, 2010, Song et al., 2010) . さらに Eye-vergence システムが安定な位置/姿勢認識に役立つことをリアプノフ法 による安定性解析により示した (Song et al., 2011).

しかし，実際のロボットシステムを用いた Eye-Vergence 性能の実証実験は行っていなかった . 先行研究を調査 したが, Eye-vergence ロボットの実証研究の報告は見当らない，光こで本論文では，提案した Eye-Vergence シス テムの動力学的利点を実験的に確認するために，ハンド部の横方向の直線軌道上を往復運動する対象物 (6DoF)へ の追従実験を行い，周波数応答特性を計測した . 本報の新規性は, Eye-vergence システムビジュアルサーボの実用 性を実証的に調べて，弚の有効性を明らかにした点にある．これにより提案した Eye-Vergence システムが高い可 追従性を持つことを示す . また , 従来の研究 (Maeda et al., 2012) の注視点の定義を，注視点が仮想平面上の点では なく空間内の点として動くことができるように改めた . 3.4 に詳しく説明する . 本報では , 紙数が多くなることを 避けるため横方向の周波数応答について述べ, 奥行き方向のビジュアルサーボ特性を実験的に確認した研究は別 報 (寇他, 2016, Kou et al, 2017) で述べることにする.

\section{3. ハンドアイビジュアルサーボ}

\section{$3 \cdot 1$ 目標軌道生成}

図 4 にハンド部と対象物の関係を示す.世界座標系を $\Sigma_{W}$ ，対象物に固定した座標系を $\Sigma_{M}$ と記述する.さらに， 実際のハンド部の座標系と光の目標座標系をとれぞれ $\Sigma_{E}, \Sigma_{E d}$ で表すこととする.ハンド部の目標状態と対象物と

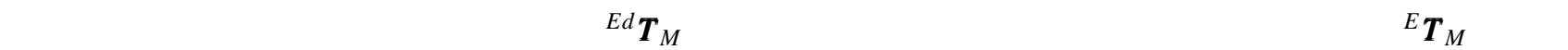
て表す .このとき,$\Sigma_{E}$ と $\Sigma_{E d}$ との差は ${ }^{E} \boldsymbol{T}_{E d}$ として表され ${ }^{E} \boldsymbol{T}_{E d}$ は以下のように記述できる.

$$
{ }^{E} \boldsymbol{T}_{E d}(t)={ }^{E} \boldsymbol{T}_{M}(t){ }^{E d} \boldsymbol{T}_{M}^{-1}(t)
$$

式 (1) は $\Sigma_{E}$ で表された任意の対象物の運動 ${ }^{E} \boldsymbol{T}_{M}(t)$ と任意のロボットハンド部の目標位置/姿勢 $\Sigma_{E d}$ で表された 


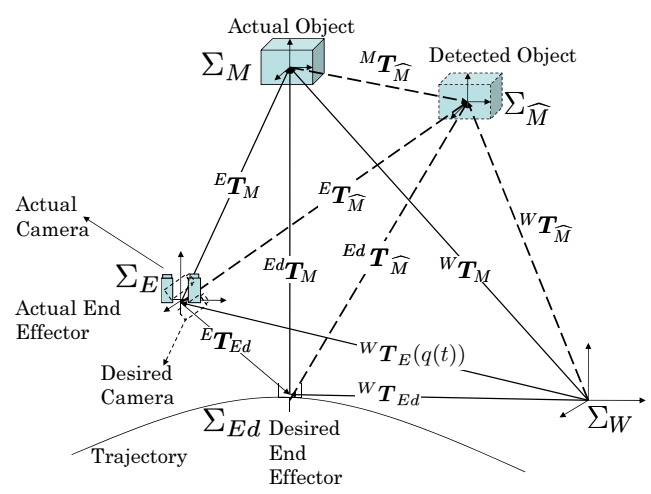

Fig. 4 Motion of the end-effector and object

対象物との相対的な時変ビジュアルサーボの目標軌道 ${ }^{E d} \boldsymbol{T}_{M}(t)$ を含む: ${ }^{E} \boldsymbol{T}_{M}(t)$ はハンド部の速度/角速度情報を フィードフォワード情報として用いる認識方法 (Song et al., 2007, Song et al., 2010) とビデオレートで入力される 動画像列に対して認識する動画像認識方法 1-step GA (Suzuki and Minami, 2005) を組み合わせたオンラインモデル ベースド認識法を使って観測される . 推定された対象物を $\Sigma_{\widehat{M}}$ で表すと，実際の物体 $\Sigma_{M}$ と検出された物体 $\Sigma_{\widehat{M}}$ の間 には, 誤差 ${ }^{M} \boldsymbol{T}_{\widehat{M}}$ が存在することが一般的である .ここでは, 式 (1) で表されるハンド部の位置/姿勢誤差 ${ }^{E} \boldsymbol{T}_{E d}(t)$ を次のように推定した物体 $\Sigma_{\widehat{M}}$ に基づいて再構成する。

$$
{ }^{E} \boldsymbol{T}_{E d}(t)={ }^{E} \boldsymbol{T}_{\widehat{M}}(t)^{\widehat{M}} \boldsymbol{T}_{E d}(t)
$$

式 (2)を時間に関して微分すると以下の式を得る .

$$
{ }^{E} \dot{\boldsymbol{T}}_{E d}(t)={ }^{E} \dot{\boldsymbol{T}}_{\widehat{M}}(t)^{\widehat{M}} \boldsymbol{T}_{E d}(t)+{ }^{E} \boldsymbol{T}_{\widehat{M}}(t)^{\widehat{M}} \dot{\boldsymbol{T}}_{E d}(t) .
$$

ここで ${ }^{\widehat{M}} \boldsymbol{T}_{E d},{ }^{\widehat{M}} \dot{\boldsymbol{T}}_{E d}$ はビジュアルサーボの目標軌道としてあらかじめ与えられ ${ }^{E} \boldsymbol{T}_{\widehat{M}},{ }^{E} \dot{\boldsymbol{T}}_{\widehat{M}}$ は 1-Step GA によって 観測される. ${ }^{E} \boldsymbol{T}_{E d}(t)$ と ${ }^{E} \dot{\boldsymbol{T}}_{E d}(t)$ は $\Sigma_{E}$ と $\Sigma_{E d}$ との位置/姿勢誤差と光の時間微分であり，コントローラを構成す る時に必要となる . 図 4 に示すように , ビジュアルサーボ過程において 0 にすべき二つの誤差が存在する . 一つ は実際の物体と検出された物体 ${ }^{M} \boldsymbol{T}_{\widehat{M}}$ の認識誤差であり，他はハンド部の目標状態と実際のハンド部 ${ }^{E} \boldsymbol{T}_{E d}$ で与え られる運動制御の誤差である。

\subsection{Multi-step GA オンライン認識法}

対象物の位置/姿勢をリアルタイムで認識するために , 本研究では遺伝的アルゴリズム $(\mathrm{GA})$ の一つの方法とし て 1-step GA(Suzuki and Minami, 2005) を利用する .この方法は，

1. 位置と姿勢を仮定した 3 次元形状と光の色で構成されたモデルを作成し，位置/姿勢を GA の遺伝子として 定義する .

2. 乥の 3 次元モデルを左右カメラへ写影する .

3. 左右カメラに撮像された 3 次元対象物とカメラ画像に写影されたモデルの相関度を計算する .

4. 相関度を GA の適合度関数として用い，位置/姿勢を表す遺伝子群を進化させる．

5. 動画一画面がメモリーに転送される時間は $9.2[\mathrm{~ms}]$ であるため，ビデオレート $33[\mathrm{~ms}]$ 内の残りの時間は， $33-9.2=23.8[\mathrm{~ms}]$ となる .この時間の間 GA で遺伝子群を 9 回進化させることができる.ただし，動画像入 カボードの仕樣は, 3 章に記載する .

6. $23.8[\mathrm{~ms}]$ の時間に進化した遺伝子の中で最も高い適合度を与えるモデルの位置/姿勢を光の時刻の 3 次元対 象物の位置/姿勢計測結果とする.

以上の (2)〜 (6) を繰り返すことで, ビデオレートで連続的に入力される動画像中の 3 次元対象物の位置/姿勢を 計測する . 以前の研究では動画一画面に対して GA を最大 1 回進化させることか限度であった (Minami and Song, 2009) . しかし , 最近のコンピュータの計算速度の向上により，本報では 9 回の進化を行うことができた .コン 


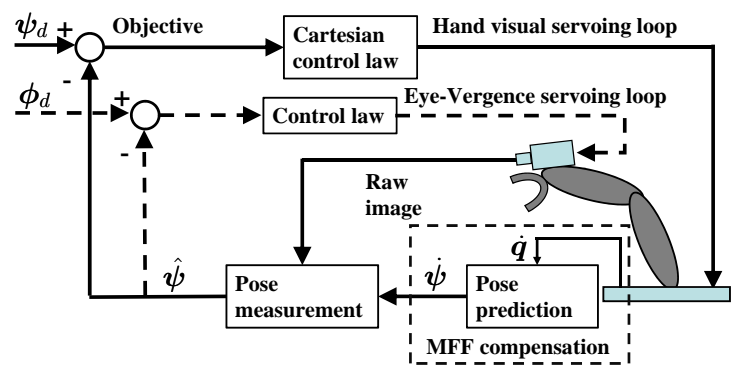

Fig. 5 Hand \& Eye-vergence Visual Servoing System . MFF is motion-feedforward referred by (Song et al., 2007) ピュータの仕樣は 3 章で述べる .したがって従来“1-step GA”と呼んでいた動画像認識方法を以後“Multi-step GA” と呼ぶことにする

\section{$3 \cdot 3$ ビジュアルサーボコントローラ}

\subsection{1 ハンドビジュアルサーボコントローラ}

提案するビジュアルサーボコントローラはハンド部の位置/姿勢制御と視線制御の二つのコントローラを組み 合わせて構成されており，谷のブロック線図を図 5 に示す.ハンドビジュアルサーボは外側のループである . 図中 , “Pose Prediction”と記したブロックに“MFF”と表記しているのは“Motion Feedforward”の略で，ハンドアイの速度 /角速度によりハンドの位置／姿勢が変化している影響を画像内の対象物の移動速度として算出し，ビデオレー トの $33[\mathrm{~ms}]$ 後の対象物位置を予測した情報を用いて GA の進化を進める方法 (Song et al., 2007) である . 前節で議 論したロボットの手先の運動軌道を用いて手先の目標速度 ${ }^{W} \dot{\boldsymbol{r}}_{d}$ を，

$$
{ }^{W} \dot{\boldsymbol{r}}_{d}=\boldsymbol{K}_{P P}{ }^{W} \boldsymbol{r}_{E, E d}+\boldsymbol{K}_{V P}{ }^{W} \dot{\boldsymbol{r}}_{E, E d},
$$

のように PD 制御則で算出する. ${ }^{W} \boldsymbol{r}_{E, E d}$ は , 図 4 で $\Sigma_{W}$ で表した $\Sigma_{E}$ の原点から $\Sigma_{E d}$ の原点までの位置べクトルで あり， ${ }^{W} \dot{\boldsymbol{r}}_{E, E d}$ は光の時間微分である ${ }^{W} \boldsymbol{r}_{E, E d},{ }^{W} \dot{\boldsymbol{r}}_{E, E d}$ は $\Sigma_{E}$ から $\Sigma_{W}$ への座標変換を使って ${ }^{E} \boldsymbol{T}_{E d}$ と ${ }^{E} \dot{\boldsymbol{T}}_{E d}$ から求 められる. $\boldsymbol{K}_{P P}$ は $\boldsymbol{K}_{P P}=\operatorname{diag}(0.4,0.4,0.4)\left[1 / \mathrm{s}\right.$ ] バネ定数， $\boldsymbol{K}_{V P}=\operatorname{diag}(0.1,0.1,0.1)$ [無次元] は粘性抵抗を表す正定 な対角行列である . ハンド部の目標位置/姿勢は ${ }^{W} \boldsymbol{\Psi}_{d}^{T}=\left[{ }^{W} \boldsymbol{r}_{d}^{T},{ }^{W} \boldsymbol{\varepsilon}_{d}^{T}\right]^{T}$ とする.${ }^{W} \boldsymbol{\varepsilon}_{d}$ はクオータニオンで表した目 標姿勢である . ハンド部の目標角速度ベクトル ${ }^{W} \boldsymbol{\omega}_{d}$ を次式で算出する .

$$
{ }^{W} \boldsymbol{\omega}_{d}=\boldsymbol{K}_{P O}{ }^{W} \boldsymbol{R}_{E}{ }^{E} \Delta \boldsymbol{\varepsilon}+\boldsymbol{K}_{V O}{ }^{W} \boldsymbol{R}_{E}^{E} \boldsymbol{\omega}_{E, E d},
$$

と与えられる .ここで , ${ }^{E} \Delta \boldsymbol{\varepsilon}$ はクォータニオンの偏差で, $\Sigma_{E}$ で表された対象物の姿勢誤差であり，Multi-step GA による認識結果 ${ }^{E} \boldsymbol{T}_{E d}$ から直接得られる. ${ }^{W} \boldsymbol{\omega}_{E, E d}$ は ${ }^{E} \boldsymbol{T}_{E d},{ }^{E} \dot{\boldsymbol{T}}_{E d}$ に含まれる姿勢変換行列 ${ }^{E} \boldsymbol{R}_{E d}$ と光の時間微分 ${ }^{E} \dot{\boldsymbol{R}}_{E d}$ と，歪対称行列 $\boldsymbol{S}(\boldsymbol{\omega})$ ，

$$
\boldsymbol{S}(\boldsymbol{\omega})=\left[\begin{array}{ccc}
0 & -\omega_{z} & \omega_{y} \\
\omega_{z} & 0 & -\omega_{x} \\
-\omega_{y} & \omega_{x} & 0
\end{array}\right]
$$

を用いると $\boldsymbol{S}(\boldsymbol{\omega})^{E} \boldsymbol{R}_{E d}={ }^{E} \dot{\boldsymbol{R}}_{E d}$ が成立するため

$$
\boldsymbol{S}(\boldsymbol{\omega})={ }^{E} \dot{\boldsymbol{R}}_{E d}{ }^{E} \boldsymbol{R}_{E d}^{-1}
$$

より ${ }^{E} \boldsymbol{\omega}_{E, E d}=\left[\omega_{x}, \omega_{y}, \omega_{z}\right]^{T}$ を決定することができる . $\boldsymbol{K}_{P O}=\operatorname{diag}(0.4,0.4,0.4)[1 / \mathrm{s}]$ はバネ定数， $\boldsymbol{K}_{V O}=$ $\operatorname{diag}(0.1,0.1,0.1)$ [無次元] は粘性抵抗を表す正定な対角行列である .

本研究で使用しているアーム型ロボット PA-10(三菱重工製) は一つの几長自由度を持っている . 本報は冗長性に関 する考察は行わないので, 第 1 リンクの目標角度 $q_{1 d}$ を 0 と設定することでこ長性を取り除く. 従って，手先の目標 位置から各リンクの目標角度を逆運動学により確定でき, ロボットハンド部の目標関節角度 $\boldsymbol{q}_{H d}=\left[0, q_{2 d}, \ldots, q_{7 d}\right]^{T}$ と角速度 $\dot{\boldsymbol{q}}_{H d}$ を以下の式で与えることにする．

$$
\boldsymbol{q}_{H d}=\boldsymbol{f}^{-1}\left({ }^{W} \boldsymbol{\Psi}_{d}\right)
$$




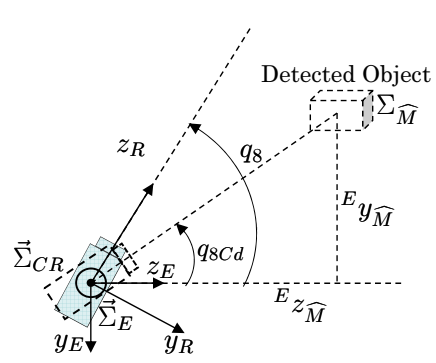

(a) Tilt angle $q_{8}$

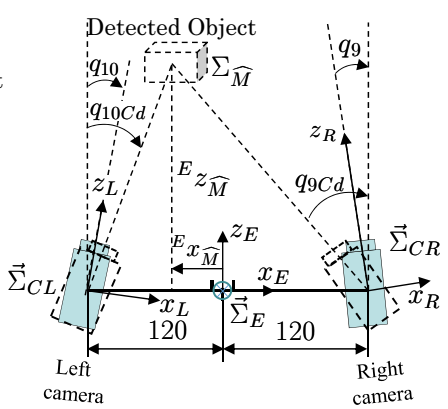

(b) Pan angle $q_{9}$ and $q_{10}$

Fig. 6 Definition of tilt and pan angles with relation of detected object

$$
\dot{\boldsymbol{q}}_{H d}=\boldsymbol{K}_{P Q}\left(\boldsymbol{q}_{H d}-\boldsymbol{q}_{H}\right)+\boldsymbol{J}^{+}(\boldsymbol{q})\left[\begin{array}{c}
{ }^{W} \dot{\boldsymbol{r}}_{d} \\
{ }^{W} \boldsymbol{\omega}_{d}
\end{array}\right]
$$

ここで, $\boldsymbol{f}^{-1}\left({ }^{W} \boldsymbol{\Psi}_{d}\right)$ は逆運動学を表し, $\boldsymbol{K}_{P Q}=\operatorname{diag}(0.2,0.2,0.2,0.2,0.2,0.2,0.2)[1 / \mathrm{s}]$ はバネ定数である.

式 (9) の右辺第 1 項はフィードバックであり，第 2 項は速度及び角速度をフィードフォワードとして与えてい る. $\boldsymbol{J}^{+}(\boldsymbol{q})$ はハンド部の位置/姿勢を関節角ベクトルで偏微分したヤコビ行列の擬似逆行列である .ここでハンド 部とは, 具体的に図 6 及び図 7 に示す $\vec{\Sigma}_{E}$ を意味する .

3.3.2 両眼転導ビジュアルサーボコントローラ

両眼転導ビジュアルサーボは図 5 のビジュアルサーボシステムの破線で示す内側のループである . 本論文では Eye-Vergence ビジュアルサーボに対して二つのパンチルトカメラを使う . カメラは手先に取り付けられており, 回 転することができる.$q_{8}$ は左右カメラ共通のチルト角を表し， $q_{9}$ と $q_{10}$ はパン角を表す. 図 6 に示すように， ${ }_{x_{\widehat{M}}}$, ${ }^{E} y_{\widehat{M}}$ および $z_{\widehat{M}}$ はハンド部座標 $\Sigma_{E}$ において検出された物体の位置を表す . Eye-vergence を制御するブロックを図 9 の中段に示す . カメラ角の望ましい角度 $\boldsymbol{q}_{C d}=\left[q_{8 C d}, q_{9 C d}, q_{10 C d}\right]^{T}$ は図 6 の中に定義されている長さを用いて以 下によって計算される .

$$
\begin{aligned}
& q_{8 C d}=\operatorname{atan} 2\left({ }^{E} y_{\widehat{M}},{ }^{E} z_{\widehat{M}}\right) \\
& q_{9 C d}=\operatorname{atan} 2\left(l_{8 R}-{ }^{E} x_{\widehat{M}},{ }^{E} z_{\widehat{M}}\right) \\
& q_{10 C d}=\operatorname{atan} 2\left(l_{8 L}+{ }^{E} x_{\widehat{M}},{ }^{E} z_{\widehat{M}}\right)
\end{aligned}
$$

ここで, $l_{8 L}=l_{8 R}=120[\mathrm{~mm}]$ は $\Sigma_{E}$ の原点からのカメラの位置を表し , カメラ視線方向の中心線を左右カメラ座標 の $z, z_{E}$, 軸とする . Eye-Vergence の目標関節角速度 $\dot{\boldsymbol{q}}_{C d}=\left[\dot{q}_{8 C d}, \dot{q}_{9 C d}, \dot{q}_{10 C d}\right]$ は，

$$
\dot{q}_{i C d}=K_{P}\left(q_{i C d}-q_{i}\right) \quad(i=8,9,10)
$$

と与えられ， $\dot{q}_{i C d}$ はパルス列としてカメラ角度制御用のパルスモータに入力される.ここで $K_{P}=1$ はバネ定数， $K_{D}$ は粘性抵抗を表す .

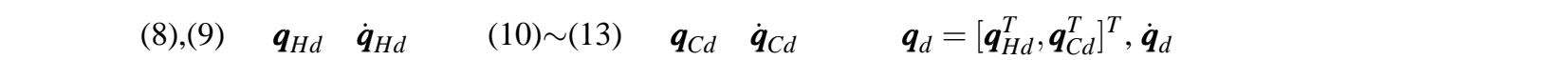
ロボットへの入カトルク $\tau=\left[\tau_{H}^{T}, \tau_{C}^{T}\right]^{T}$ は次式によって決定する .

$$
\boldsymbol{\tau}=\boldsymbol{K}_{S P}\left(\boldsymbol{q}_{d}-\boldsymbol{q}\right)+\boldsymbol{K}_{S D}\left(\dot{\boldsymbol{q}}_{d}-\dot{\boldsymbol{q}}\right)
$$

上式の $\boldsymbol{K}_{S P}$ はバネ定数, $\boldsymbol{K}_{S D}$ は粘性抵抗を表す行列である . 式(14) は, ロボットのサーボアンプ内の演算であり コントローラの出力は , 式 (9)の $\dot{\boldsymbol{q}}_{H d}$ と式 (13)の $\dot{q}_{i C d}(i=8,9,10)$ である .

ロボットのハンド部とカメラ視線方向の制御式 (14) は図 9 の上段の右側のブロックに位置している . ハンド部 の位置/姿勢を制御するブロックは上段の左側に示されており, Eye-vergence 制御ブロックの出力 $\boldsymbol{q}_{C d}, \dot{\boldsymbol{q}}_{C d}$ と八 ンド部の出力 $\boldsymbol{q}_{H d}, \dot{\boldsymbol{q}}_{H d}$ と合わせて制御出カトルク $\tau$ を決定している. 


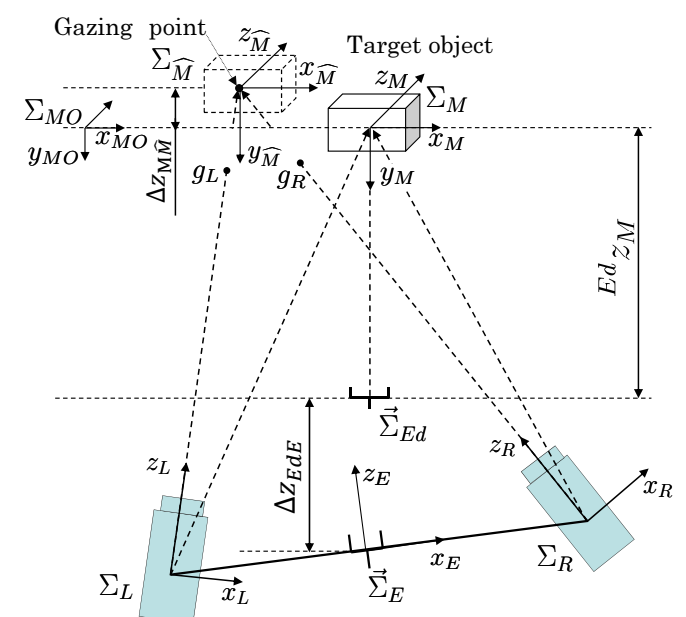

Fig. 7 Cameras' gazing point

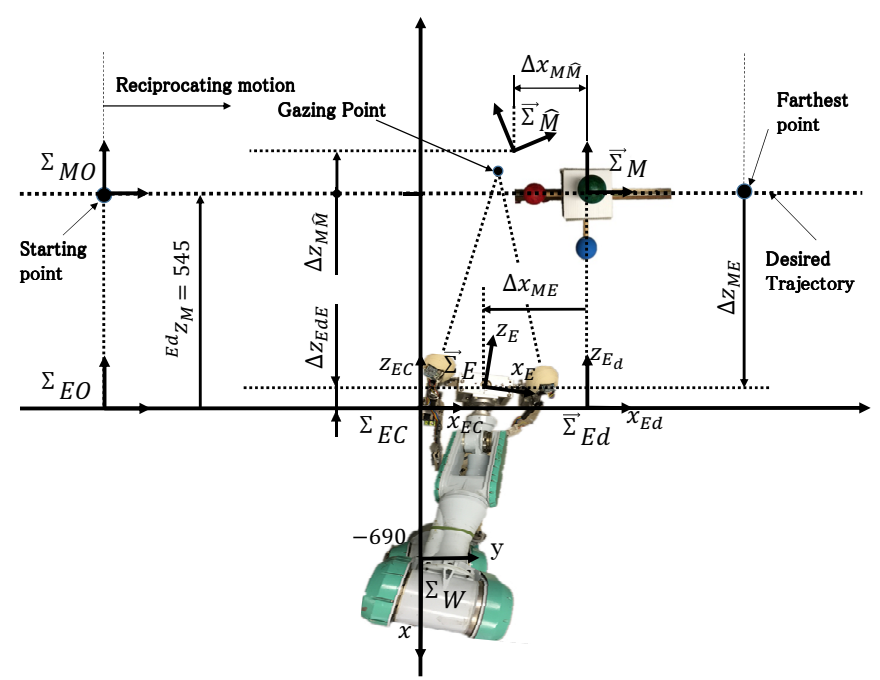

Fig. 8 Target object and definition of coordinates depicted in the X-z plane of $\Sigma_{E C}$. Initial position of the object is represented by $\Sigma_{M O}$; actual object $\vec{\Sigma}_{M}$; detected object $\vec{\Sigma}_{\widehat{M}}$; initial position of the hand $\Sigma_{E O}$; actual end effector $\vec{\Sigma}_{E}$; and desired end-effector $\vec{\Sigma}_{E d}$. At this moment orientation ${ }^{E} \Delta \boldsymbol{\varepsilon}$ in Eq.(5) is not zero vector.

図の最下段は, ロボットの順運動学を示している .この関係と左右カメラへの写影によりカメラ画像に撮像され たマーカーの位置/姿勢を MFF(Motion Feedforward) による補正 (宋, 見浪, 2010, 宋他, 2010) を行った後 Multi-step GA により動画像を実時間認識している .

\subsection{Gazing point $の$ 定義}

カメラの視線方向か対象物をカメラ画像の中央で撮像するように制御されているかどうかを評価するため，力 メラの注視点を定義する. 図 7 に示すように以前の研究 (Maeda et al., 2012) では左カメラの視線方向と $x_{M O}-y_{M O}$ 平面の交点 $g_{L}$ を左カメラの注視点と定義し, 右カメラの注視点で $g_{R}$ と定義していた . しかし, 左右カメラが兰 れ光れ $g_{L}, g_{R}$ の注視点を持っていることは，不自然であり，本報では図 7 中の “Gazing Point”に示すように左右 カメラの視線交点を注視点と定義した . 図 8 に示す左右カメラの視線方向が交わる点をカメラの注視点とし, こ れを Gazing point と呼ぶ. 2 台のカメラは共通の板の上に設置され图 6(a) に示す $q_{8}$ によって回転させる構造であ るため左右カメラの視線は 3 次元空間内に必ず交点を持つ.また 2 台のカメラの視線方向はハンド部に固定され ている $\vec{\Sigma}_{E}$ の $x_{E}-z_{E}$ 平面内で走査されるから $\vec{\Sigma}_{E}$ で表された Gazing Point $の \mathrm{y}$ 座標は常に $-100[\mathrm{~mm}]$ である .

図 13 に示すように $\Sigma_{E}$ で表された Gazing Point は $q_{9}, q_{10}$ で表される.ただし $0<q_{9}, q_{10}<\pi / 2$ とする.図 12 の関係より次式が得られる . 


$$
\frac{E_{z_{G}}}{120+{ }^{E} x_{G}}=\tan \left(\frac{\pi}{2}-q_{10}\right), \quad \frac{E_{z_{G}}}{240-{ }^{E} x_{G}}=\tan \left(\frac{\pi}{2}-q_{9}\right)
$$

この 2 式を連立させて ${ }^{E} x_{G},{ }^{E} z_{G}$ を求める.ハンド部座標系 $\Sigma_{E}$ から見た Gazing point ${ }^{E} \boldsymbol{P}=\left[{ }^{E} x_{G}, 0,{ }^{E} z_{G}\right]^{T}$ は,

$$
{ }^{E} \boldsymbol{P}=\left[\begin{array}{c}
\frac{240 \tan \left(\frac{\pi}{2}-q_{9}\right)}{\tan \left(\frac{\pi}{2}-q_{10}\right)+\tan \left(\frac{\pi}{2}-q_{9}\right)}-120 \\
0 \\
\frac{240 \tan \left(\frac{\pi}{2}-q_{10}\right) \tan \left(\frac{\pi}{2}-q_{9}\right)}{\tan \left(\frac{\pi}{2}-q_{10}\right)+\tan \left(\frac{\pi}{2}-q_{9}\right)}
\end{array}\right]
$$

と求まる.

\section{5 クォータニオン姿勢表現}

ある物体に固定した座標系 $\Sigma_{A}$ を単位べクトル $\boldsymbol{k}$ 回りに角度 $\theta$ 回転させると $\Sigma_{B}$ と一致する場合, クォータニオ ンの姿勢表現 $\boldsymbol{Q}$ はアングル/アクシスのパラメータ $(\boldsymbol{k}, \boldsymbol{\theta})$ を用いて次式で表される (Natale, 2003) .

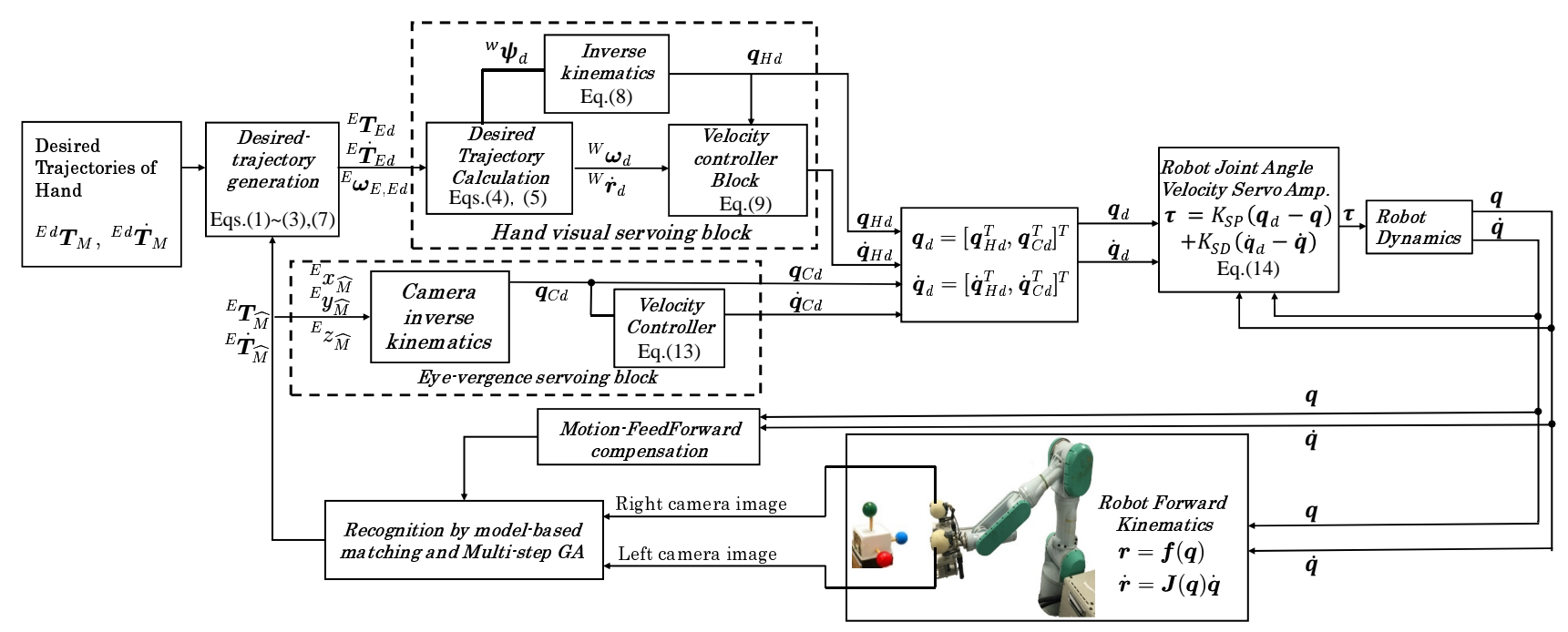

Fig. 9 Block diagram of the hand and eye-vergence visual servoing system

$$
\boldsymbol{Q}=[\eta, \boldsymbol{\varepsilon}],\left(\eta=\cos \frac{\theta}{2}, \boldsymbol{\varepsilon}=\sin \frac{\theta}{2} \boldsymbol{k}\right)
$$

このとき

$$
\boldsymbol{\varepsilon}=\left[\varepsilon_{1}, \varepsilon_{2}, \varepsilon_{3}\right]^{T}=\sin \frac{\theta}{2}\left[k_{x}, k_{y}, k_{z}\right]^{T}
$$

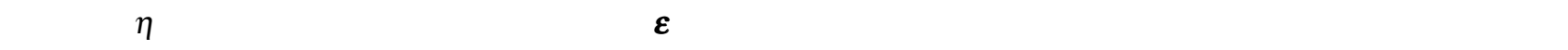
め次式によって制限される .

$$
\eta^{2}+\boldsymbol{\varepsilon}^{T} \boldsymbol{\varepsilon}=1
$$

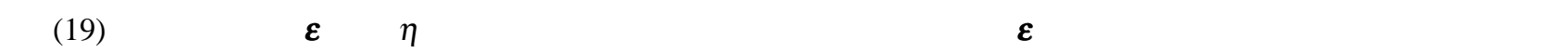
と違い, 回転軸 $\boldsymbol{k}$ と回転角 $\theta$ で表したクォータニオン $\{\eta, \boldsymbol{\varepsilon}\}$ と回転軸 $-\boldsymbol{k}$ と回転角 $-\theta$ で表した $\{\eta, \boldsymbol{\varepsilon}\}$ は一致し， アングル/アクシス 表現の任意性は解決されている . また,$\theta=0$ のとき , $\boldsymbol{\varepsilon}=(0,0,0), \eta=1$ となり，kが不定 となるアングル/アクシスの特異姿勢の問題も解決されている . 

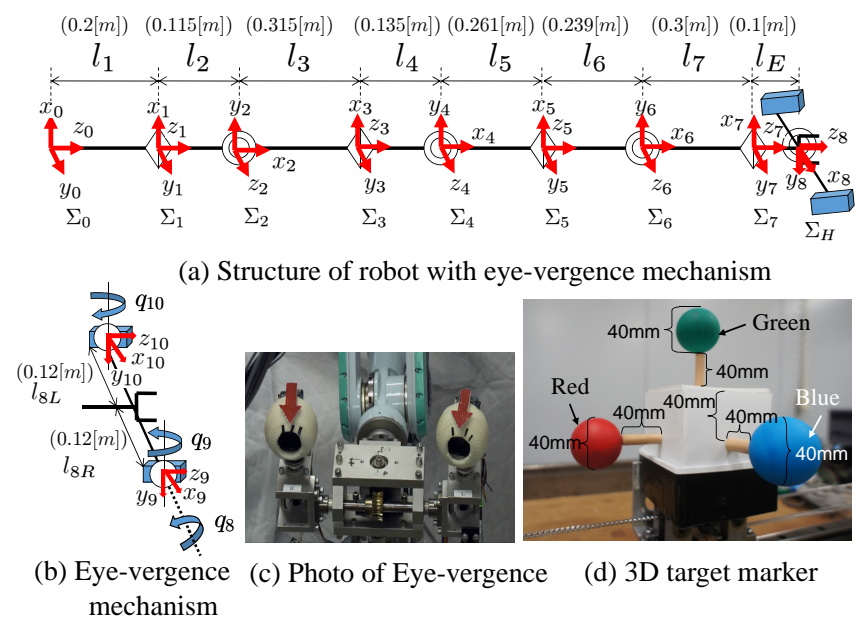

Fig. 10 Frame structure of eye-vergence manipulator

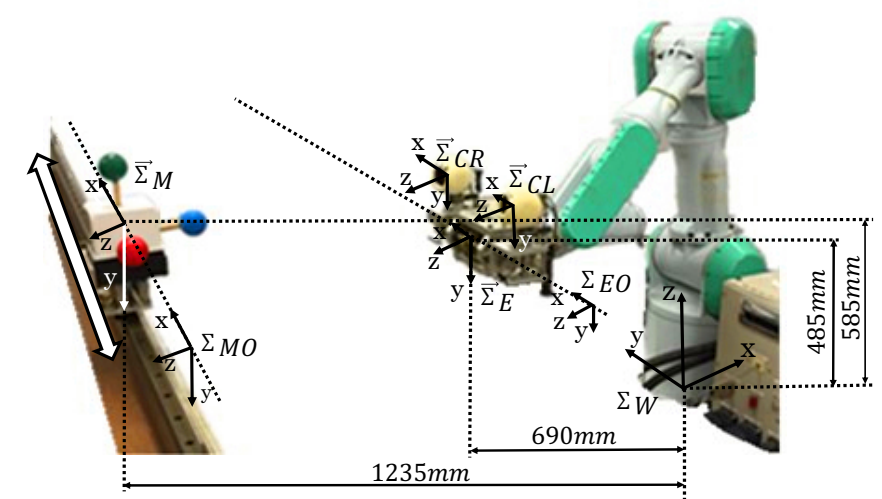

Fig. 11 Layout of the visual-servoing experiment. Refer to section $4 \cdot 2$ for the definition of symbols in the figure.

4. ハンドアイビジュアルサーボ実験

\section{$4 \cdot 1$ 実験環境}

提案したビジュアルサーボシステムの有効性を実機によって確認する．アーム型ロボットは, PA-10(三菱重工 製)を用いる.PA-10 の手先には SONY 製のカメラ (CCD-TRV86 (1/6 インチ CCD), 焦点距離 : $\mathrm{f}=3.6[\mathrm{~mm}]$, 視 野角 : $\alpha=38[\mathrm{deg}]$, ビデオレート 30[fps]) を二台取り付け，複眼で対象物を観測する．画像認識および PA-10の 制御を行う PCには, DELL Optiplex (OS : windows XP , CPU : i7-3370，3.40GHz) を使用しており，画像入力ボー ドはインターフェイス社製 PCI5520 を用いている . マニピュレータの構造と，ハンド部座標系 $\Sigma_{E}$ を基準として表 したカメラの構造を図 10(a) と (b) に示す . 実験したシステムでは，両眼パン角のみを Eye-vergence として制御し， ロール，チルト角制御については，マニピュレータの第 1 軸から第 7 軸の制御を用いる.対象物は图 10 に示すよ うに赤, 緑, 青のボール (左 : 赤, 上 : 緑, 手前 : 青) を組み合わせた $3 \mathrm{D}$ マーカであり，ボールの直径は $40[\mathrm{~mm}]$, ボールの中心とマーカの中心点の距離は $100[\mathrm{~mm}]$ である . 3 次元マーカーは, ロボットとのハンド部との位置・姿 勢 6 変数の偏差を測定するために設定する . 具体的な把持対象物を想定できる場合には, 弚の形状の特徵を利用 した位置・姿勢計測を行うことができる . 具体的な把持対象物を設定して著者が行った研究としては, 服をハン ドリングするロボット (Phyu et al., 2017) , フィルタプレス装置のろ布交換システム (見浪他, 2015) と顔認識ビジュ アルサーボシステム (Oonishi et al., 2013) の研究がある .

\section{$4 \cdot 2$ 実験内容}

実験における対象物とマニピュレータの関係を図 11 に示す. $\Sigma_{W}$ は床に固定された作業座標系, $\vec{\Sigma}_{C L}, \vec{\Sigma}_{C R}$ は左 右のカメラに固定された座標系， $\vec{\Sigma}_{E}$ はハンド部座標系である. $\vec{\Sigma}_{E}$ などの矢印はこの座標系か空間に固定されてい るのではなく，動く座標系であることを示している . 図左側の白い矢印は対象物の移動方向を示す . 作業空間に固 定されたハンド部 $\vec{\Sigma}_{E}$ の初期位置の座標系を $\Sigma_{E O}$, ハンド部 $\vec{\Sigma}_{E}$ の往復運動の中央点の座標系を $\Sigma_{E C}$ と物体の初期 


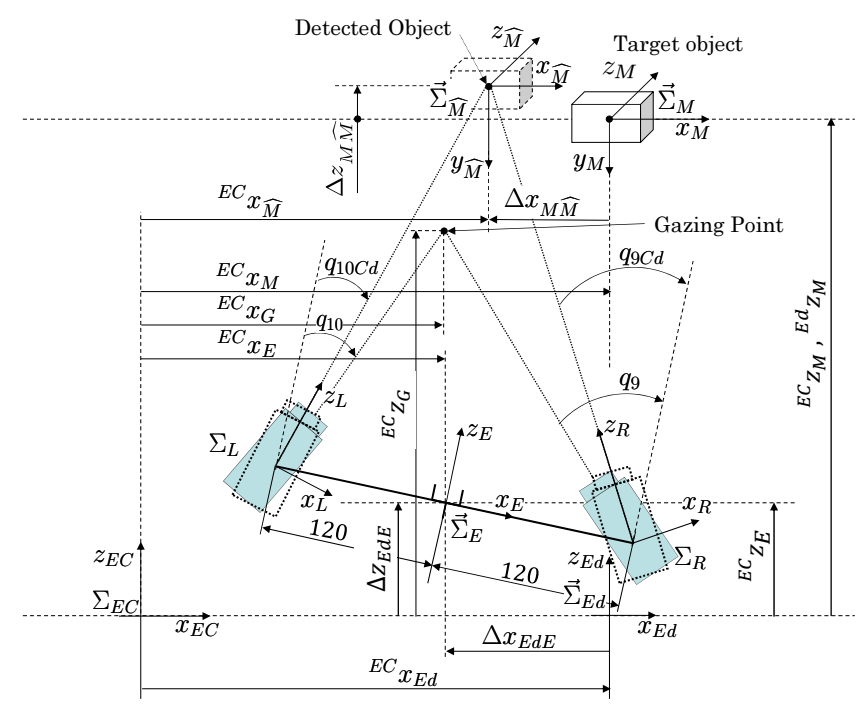

Fig. 12 Enlarged drawing of Fig.8 with gazing point. As shown in Eq.(22) ${ }^{E d} \boldsymbol{\psi}_{M}$ is desired pose relationship between object and end-effector with respect to coordinate frame $\vec{\Sigma}_{E d}$. Refer to Eq.(10), Eq.(11), Eq.(12), Eq.(23), Eq.(24) and Eq.(25) for the related symbols in the figure.

位置の座標系を $\Sigma_{M O}$ と定義する $\left(\Sigma_{E C}\right.$ と $\Sigma_{M O}$ は図 9 に示されている).$\Sigma_{W}$ から $\Sigma_{E O}, \Sigma_{E C}$ と $\Sigma_{M O}$ への同次変換行 列は以下のように与えられる .

$$
{ }^{W} \boldsymbol{T}_{E O}=\left[\begin{array}{cccc}
0 & 0 & -1 & -690[\mathrm{~mm}] \\
1 & 0 & 0 & -150[\mathrm{~mm}] \\
0 & -1 & 0 & 485[\mathrm{~mm}] \\
0 & 0 & 0 & 1
\end{array}\right],{ }^{W} \boldsymbol{T}_{E C}=\left[\begin{array}{cccc}
0 & 0 & -1 & -690[\mathrm{~mm}] \\
1 & 0 & 0 & 0[\mathrm{~mm}] \\
0 & -1 & 0 & 485[\mathrm{~mm}] \\
0 & 0 & 0 & 1
\end{array}\right],{ }^{W} \boldsymbol{T}_{M O}=\left[\begin{array}{cccc}
0 & 0 & -1 & -1235[\mathrm{~mm}] \\
1 & 0 & 0 & -150[\mathrm{~mm}] \\
0 & -1 & 0 & 585[\mathrm{~mm}] \\
0 & 0 & 0 & 1
\end{array}\right]
$$

図 11 の白矢印方向に周期直線運動する 3D マーカの運動は次式で与える .

$$
{ }^{W} \boldsymbol{T}_{M}=\left[\begin{array}{cccc}
0 & 0 & -1 & -1235[\mathrm{~mm}] \\
1 & 0 & 0 & -150 \cos (\omega t)[\mathrm{mm}] \\
0 & -1 & 0 & 585[\mathrm{~mm}] \\
0 & 0 & 0 & 1
\end{array}\right]
$$

図 11 , 図 10 よりマーカーは $\Sigma_{W}$ の $\mathrm{y}$ 軸方向に周期運動し, 式 (21) も $\mathrm{y}$ 軸方向の位置が変化することが分かる. 対 象物と手先の目標位置/姿勢関係は, 図 8 の $\vec{\Sigma}_{M}$ と $\vec{\Sigma}_{E d}$ の関係で時不変であり

$$
{ }^{E d} \boldsymbol{\Psi}_{M}=[0,-100[\mathrm{~mm}], 545[\mathrm{~mm}], 0,0,0]
$$

\section{と与えている．}

\section{$4 \cdot 3$ 計測する位置/姿勢誤差の定義}

手先の実際の位置/姿勢 $\vec{\Sigma}_{E}$ や認識した対象物の位置/姿勢 $\vec{\Sigma}_{\widehat{M}}$ など各座標系の関係を図 8 に示す. $\vec{\Sigma}_{E}, \vec{\Sigma}_{E d}$ ， $\vec{\Sigma}_{M}$ と $\vec{\Sigma}_{\widehat{M}}$ は全て世界座標系 $\Sigma_{W}$ で表された動座標系であり， $\Sigma_{E O} ， \Sigma_{E C}$ と $\Sigma_{M O}$ は世界座標系 $\Sigma_{W}$ を規準に固定さ れている .

マーカーは図 8 の $\Sigma_{M O}$ をスタートし，式 (21) に従って周期運動する . 図 8 の $\vec{\Sigma}_{\widehat{M}}$ は Multi-step GA で認識され たマーカーの位置/姿勢を表す．

図 12 に示すように $\Sigma_{E C}$ から見た対象物 $\vec{\Sigma}_{M}$ の原点の $\mathrm{x}$ 軸位置を ${ }^{E C} x_{M}$, 同樣に手先の $\mathrm{x}$ 軸位置を ${ }^{E C} x_{E}$, 認識し た対象物の $\mathrm{x}$ 軸位置を ${ }^{E C} x_{\widehat{M}}$ と表す. $\vec{\Sigma}_{M}$ と $\vec{\Sigma}_{\widehat{M}}$ の関係と Gazing Point を図 12 に示す. $\vec{\Sigma}_{M}$ と Gazing Point の差で 


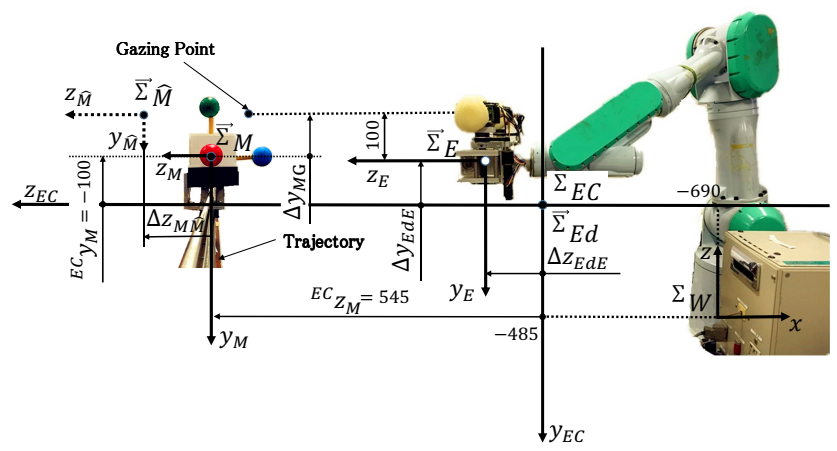

Fig. 13 3D maker and coordinates in the y-z plane of $\Sigma_{E C}$. Refer to Eq.(23), Eq.(24) and Eq.(25) for the related symbols in the figure.

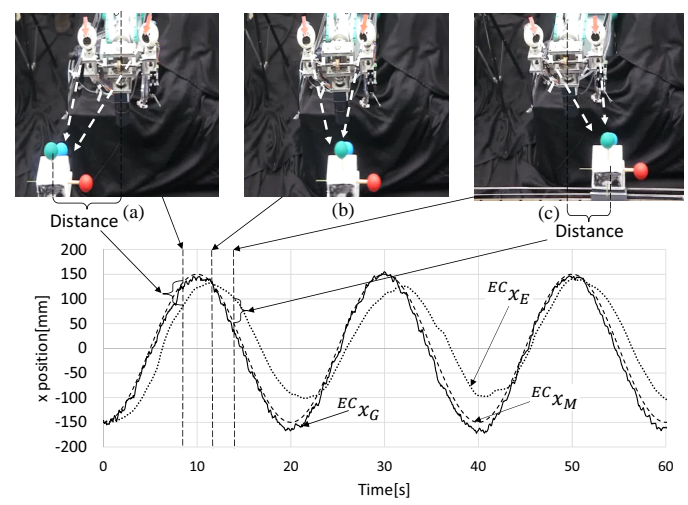

Fig. 14 Eye-vergence system and object position

ある注視誤差 $\left[\Delta x_{M G}, \Delta y_{M G}, \Delta z_{M G}\right]$ を

$$
\Delta p_{M G}={ }^{E C} p_{M}-{ }^{E C} p_{G} \quad(p=x, y, z)
$$

と定義する . また,$\Sigma_{E C}$ で表された $\Sigma_{M}$ の原点と $\vec{\Sigma}_{\widehat{M}}$ の原点の差である認識の追従誤差 $\left[\Delta x_{M \widehat{M}}, \Delta y_{M \widehat{M}}, \Delta z_{M \widehat{M}}\right]$ を

$$
\Delta p_{M \widehat{M}}={ }^{E C} p_{M}-{ }^{E C} p_{\widehat{M}} \quad(p=x, y, z)
$$

と定義する．さらに，ハンド部目標座標 $\vec{\Sigma}_{E d}$ に対するハンド部座標 $\vec{\Sigma}_{E}$ の追従誤差 $\left[\Delta x_{E d E}, \Delta y_{E d E}, \Delta z_{E d E}\right]$ を，

$$
\Delta p_{E d E}={ }^{E C} p_{E d}-{ }^{E C} p_{E} \quad(p=x, y, z)
$$

と定める.図 13 には, 図 12 で示すことができない $\Sigma_{E C}$ の y-z 平面の $\vec{\Sigma}_{\widehat{M}}, \vec{\Sigma}_{M}, \vec{\Sigma}_{E}$ の関係を示しており，式 (23) の $\Delta y_{M G}$ ，式 (25)の $\Delta y_{E d E}$ を図示している.Gazing Point が対象物に遅れなく追従してさらにハンド部 $\vec{\Sigma}_{E}$ も追従 しているとき, $\Delta p_{M G}=\Delta p_{E d E}=0(p=x, y, z)$ が満たされている.

\section{$4 \cdot 4$ 実験結果}

\subsubsection{Eye-vergence $の$ 効果}

图 14 は図 10 に示すマーカーの位置/姿勢の 6 変数を Multi-step GA で認識させる条件の下, 対象物の運動周 期 $\mathrm{T}=20[\mathrm{~s}](\omega=2 \pi / T=0.314[\mathrm{rad} / \mathrm{s}])$ の場合の追従結果のデータとして手先と対象物及び Gazing Point の位置関係

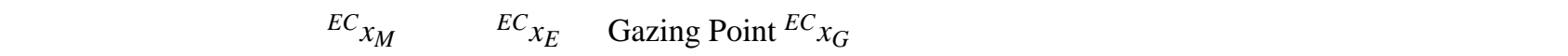
表す. 図の上部の写真 (a), (b) , (c) に示す白い矢印はカメラの視線を示す. 図 14(b) では, ハンド部 $\vec{\Sigma}_{E}$ は対象物 の直前に位置している.このため, 写真 (b) に対応する時刻のグラフでは, ${ }^{E C} x_{E}$ と ${ }^{E C} x_{G}$ が重なっており, $\vec{\Sigma}_{E}$ と Gazing Point の移動方向の誤差がゼロに近いことが分かる . (a) と (c) に示す時刻では, 手先は対象物を追従できて いない . ハンド部 $\vec{\Sigma}_{E}$ の位置 $E C_{X_{E}}$ はマーカーの位置 $E C_{X_{M}}$ に対して振幅は減少し，位相も遅れていることが分か る.一方, Gazing Point の位置 ${ }^{E C} x_{X_{G}}$ と対象物の位置 $E C_{x_{M}}$ を比較すると, ${ }^{E C_{x_{M}}}$ に対し, ${ }^{E C_{x_{G}}}$ はゲイン, 位相とも 
微小な差で追跡していることから Eye-vergence システムは対象物に対して Gazing Point をほぼ一致させることが でき，ビジュアルサーボフィードバックを維持しやすいことが分かる . ハンドに固定されている平行固定カメラハ

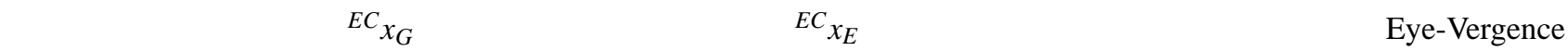
システムは固定カメラシステムの欠点を補っていることが分かる .

4.4.2 与えられる軌道実験

ビジュアルサーボによるロボットの軌道追従は, 認識の時間遅れとロボットの運動の遅れの両方を含む . この ため, ここではマーカーの動きである式 (21) の ${ }^{W} \boldsymbol{T}_{M}$ を ${ }^{E} \boldsymbol{T}_{M}$ に変換し, 図 9 の ${ }^{E} \boldsymbol{T}_{\widehat{M}}$ として用いることで式 (24) が $\Delta p_{M \widehat{M}}=0$ を満たす場合について考える.これは認識の遅れと認識誤差のない場合を想定していることと等価 であり，ロボットの運動制御性能のみに関する考察をすることができる .

この直接位置/姿勢指示值を与える場合の実験結果を図 15 に示す . $\omega=0.314[\mathrm{rad} / \mathrm{s}]$ (周期 20[s]) の場合を (a) に， $0.628[\mathrm{rad} / \mathrm{s}]$ (周期 $10[\mathrm{~s}]$ ) の場合を (b) に，1.256[rad/s] (周期 5[s]) の場合を (c) に示す . ${ }^{E C} x_{M}$ は対象物の $\mathrm{x}$ 座標であ り， ${ }^{E C} x_{X_{E}}$ と記した点線はハンド部 $\vec{\Sigma}_{E}$ の追跡結果を表す. ${ }^{E C} x_{X_{G}}$ と指示している実線は Eye-Vergence システムの追 跡能力を表している. 図中 (a) (c) のすべてで ${ }^{E C} x_{G}$ は ${ }^{E} C_{x_{M}}$ に一致しており，Gazing Point は対象物位置に遅れな く追従していることが分かる.各実験は 60[s] 間行い，さらに周期 30[s] (0.209[rad/s])，25[s] (0.251[rad/s])，20[s] $(0.314[\mathrm{rad} / \mathrm{s}]), 15[\mathrm{~s}](0.419[\mathrm{rad} / \mathrm{s}]), 10[\mathrm{~s}](0.628[\mathrm{rad} / \mathrm{s}])$ と $5[\mathrm{~s}](1.256[\mathrm{rad} / \mathrm{s}])$ の実験データによりゲイン曲線と位相曲 線を描いて図 15(d) と (e) に示す. (d) の実線(1) (a) に定義されている $a_{x M}, a_{x G}$ を用いて計算した $20 \log \left(a_{x G} / a_{x M}\right)$ を 表している.さらに(d)の破線(2)は, $20 \log \left(a_{x E} / a_{x M}\right)$ を示している .(e)の位相曲線の中で, 実線(1)は $\angle E C_{x_{G}}-\angle{ }^{E C} x_{M}$

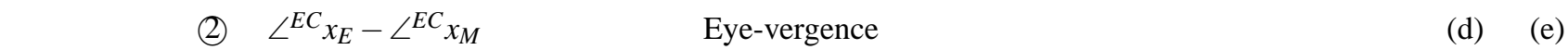

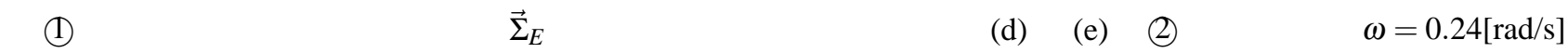
までは, ハンド $\vec{\Sigma}_{E}$ のx 座標位置は, 対象物に追従できている.また，(d)の(2)の破線で表されたハンド部 $\vec{\Sigma}_{E}$ のゲ イン特性は一次遅れ系で近似できることが分かる . 折点周波数は (d) の中のA)で示す $\omega=0.24[\mathrm{rad} / \mathrm{s}]$ である . (d) において追跡される対象物の動きの周波数の増加により，ゲインが減少することが分かる . ハンド部 $\vec{\Sigma}_{E}$ の振幅は カメラの Gazing Point の振幅より徐々に小さくなる . (e) の(2)に示すハンド部 $\vec{\Sigma}_{E}$ の位相も遅れている . しかしな がら , (d) の(1)の $20 \log \left(a_{x G} / a_{x M}\right)$ で表された Eye-Vergence システムのゲイン特性は , ゲインがほぼ $0[\mathrm{~dB}]$ である ことから $\omega=1.256[\mathrm{rad} / \mathrm{s}]$ までの範囲ではカメラの視界の中央に物体を常に捉えつづけることができている . (e) の(1)示す Eye-Vergence の位相も遅れはほとんどない . 以上により Eye-Vergence の運動特性は，ハンドの運動特 性より優れており，対象物の追跡性能が良いことが期待される .

\subsection{3 位置追跡実験}

図 16 には対象物の $\mathrm{x}, \mathrm{y}$ と $\mathrm{z}$ 座標を Multi-step GA で認識し，制御を行った場合の対象物，手先と Gazing Point の時間応答波形を示す. 姿勢については常に正しい值である $\boldsymbol{\varepsilon}=0$ を与えている. 対象物の目標姿勢は, 式 (21) より $\boldsymbol{\varepsilon}_{d}=[0,0,0]$ であり，式(5)の中で, ${ }^{E} \Delta \boldsymbol{\varepsilon}=0$ となる .この場合位置のみをビジュアルフィードバックで制御 している状態であり，従ってロボットのハンド部 $\vec{\Sigma}_{E}$ の姿勢は $\boldsymbol{\varepsilon}_{d}$ と一致しており誤差は生じていない . 図 16 の (a) , (b) 及び (c) と図 15 の光れらを比較すると同じ周期の実験で Gazing Point $の$ 位置 $E C_{x_{G}}$ と対象物の位置 $E C_{x_{M}}$ の偏差が図 15 の時のものに比べて大きくなる .つまり認識の誤差が存在する . 図 16 の (d) と (e)のデータは周期 $30[\mathrm{~s}] ， 25[\mathrm{~s}] ， 20[\mathrm{~s}] ， 15[\mathrm{~s}] ， 10[\mathrm{~s}]$ 及び5[s] の物体，Gazing Point と手先の追従実験結果の最大の振幅を乥れ光れ図 15 と同樣に表している.図 16 の(2)に示すハンド部 $\vec{\Sigma}_{E}$ の追従特性は図 15 の時の状況に比べて大差がない . また， 図 16 の (e)の(1)示すように Eye-vergence システムの位相の追跡特性は対象物の運動速度が速くなることによっ てわずかに遅れる . 従って , システムは認識過程のために少し遅くなるが , (d) の(1)よりゲイン曲線で表された対 象物の追跡性能にはほぼ影響を与えていないことが分かる .

\subsection{4 位置/姿勢追跡実験}

位置/姿勢の 6 变数を Multi-step GA で実時間認識しハンド部 $\vec{\Sigma}_{E}$ の位置/姿勢及び Gazing Point の制御を行っ た . 位置の中で , $\mathrm{x}$ の応答を $\omega=0.314,0.628,1.256[\mathrm{rad} / \mathrm{s}]$ と変化させて調べた結果を図 17 に示す .

図 17 の (a.1) は $\omega=0.314$ ( $\mathrm{T}=20[\mathrm{~s}]),(\mathrm{b} .1)$ は $\omega=0.628$ ( $\mathrm{T}=10[\mathrm{~s}]),(\mathrm{c} .1)$ は $\omega=1.256$ ( $\mathrm{T}=5[\mathrm{~s}])$ の場合の， ${ }^{E C} C_{x_{M}},{ }^{E C} x_{x_{E}},{ }^{E C} x_{x_{G}}$ を示している.また (a.2)，(b.2)，(c.2) は光れ午れ x 軸方向のハンド部 $\vec{\Sigma}_{E}$ の遅れを意味す る $\Delta x_{E d E}$ と Eye-vergence の遅れを意味する $\Delta x_{M G}$ を表している. 图 16(a) (c) に示す ${ }^{E} C_{x_{G}}$ と図 17(a) (c) に示す ${ }^{E C} x_{x_{G}}$ を比較すると，図 17(a)，(b) の ${ }^{E C} x_{G}$ の誤差が増大していることが分かる.特に，両図について時刻 $20[\mathrm{~s}]$, 


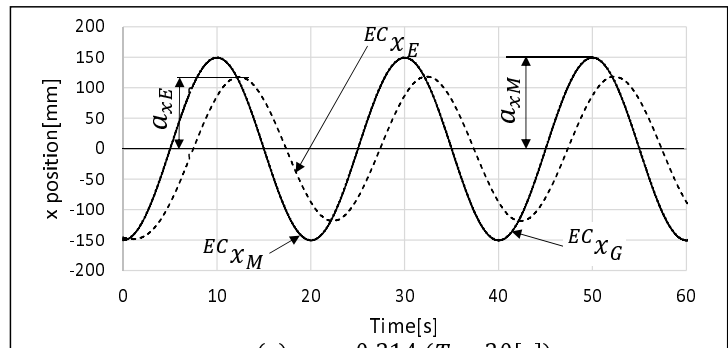

(a) $\omega=0.314(T=20[\mathrm{~s}])$

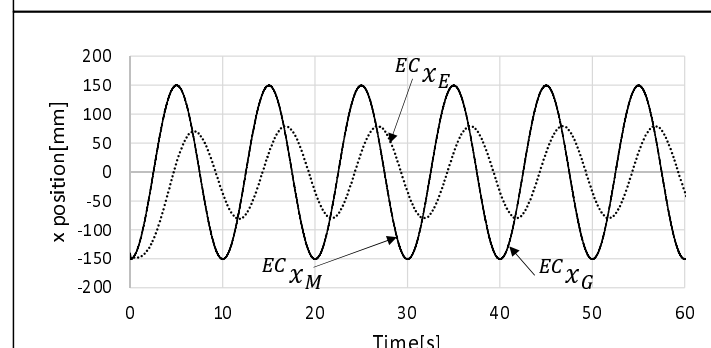

(b) $\omega=0.628(T=10[\mathrm{~s}])$

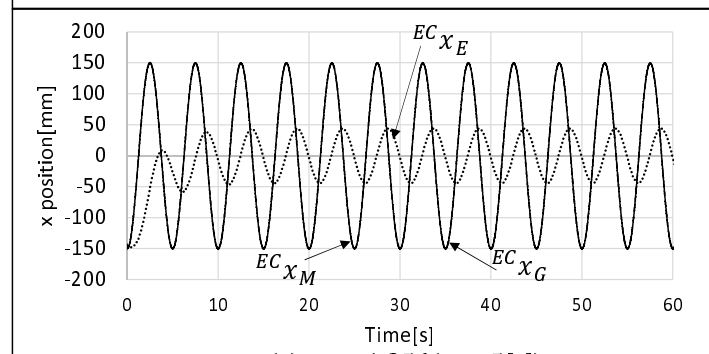

(c) $\omega=1.256(T=5[\mathrm{~s}])$

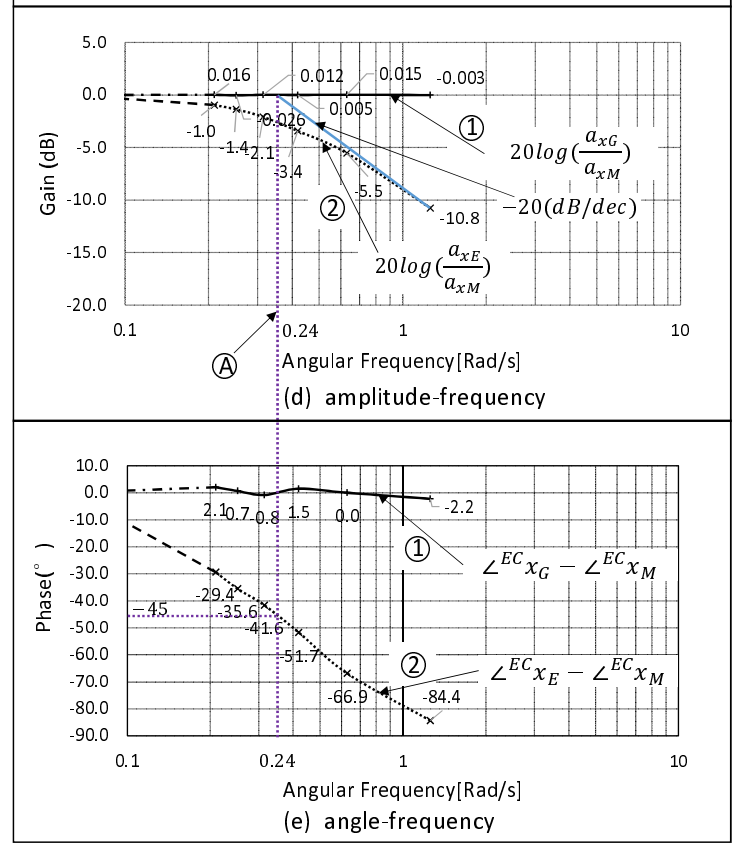

Fig. 15 Movements of target ${ }^{E C} x_{M}$, end effector ${ }^{E C} x_{E}$ and gazing point ${ }^{E C} x_{G}$ on the x-axis direction in the center coordinate system of hand $\Sigma_{E C}$. The amplitudes of end-effector $a_{x E}$ and target $a_{x M}$. True object's desired pose is directly given to the system, which guarantees the pose tracking recognition error to be zero, so in this figure we can evaluate only the delays made by dynamic influences, showing the camera can track the object much better than the end-effector.

40[s] 付近を比較するとよく分かる .

姿勢認識が増加するため, 図 17 の (c.1)に見られるように, ${ }^{E C} x_{x_{G}}$ の振幅は, ${ }^{E C} C_{x_{M}}$ の振幅 $( \pm 150[\mathrm{~mm}])$ とほぼ同 


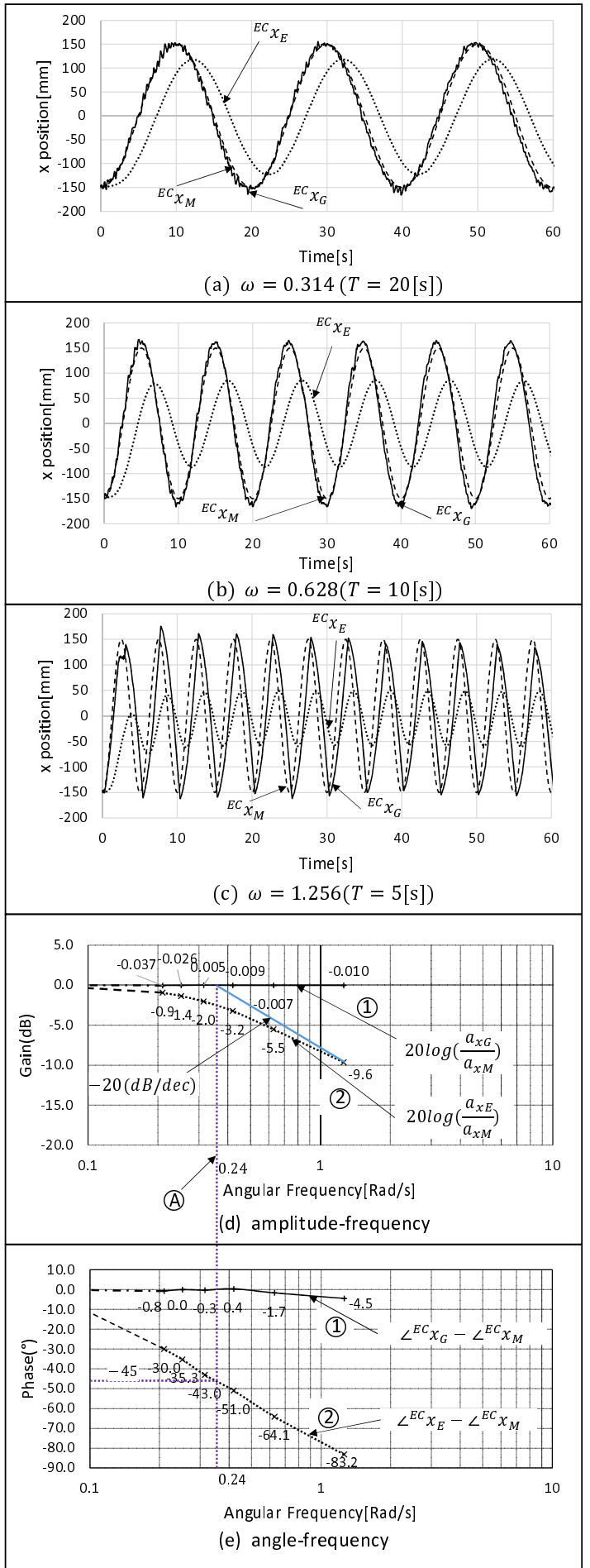

Fig. 16 Movements of target ${ }^{E C} x_{M}$, end effector ${ }^{E C} x_{E}$ and gazing point ${ }^{E C} x_{G}$ on the x-axis direction in the center coordinate system of hand $\Sigma_{E C}$. The amplitudes of end-effector $a_{x E}$ and target $a_{x M}$. The object's pose $\varepsilon_{1}$, $\varepsilon_{2}$ and $\varepsilon_{3}$ are assumed to be given to servoing controller and the object's pose $\mathrm{x}, \mathrm{y}$ and $\mathrm{z}$ are recognized by camera.

程度であるため $\mathrm{x}$ 軸方向の Gazing Point 位置 ${ }^{E} C_{X_{G}}$ は対象物の動き $E^{E} x_{M}$ に追従していることが分かる . しかし， ${ }^{E C} x_{x_{M}}$ と ${ }^{E C} C_{x_{G}}$ の位相には遅れが存在する. 図 17 の (c.1) を見るとハンド部 $\vec{\Sigma}_{E}$ の振幅 ${ }^{E} C_{x_{E}}$ は $\pm 50[\mathrm{~mm}]$ 程度に減 少しており， ${ }^{E C} x_{M}$ は $\pm 150[\mathrm{~mm}]$ で周期運動をしていることを考えると，Multi-step GA は認識を継続しているが

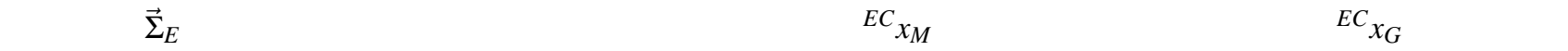
できていることは，ロボット全体の慣性が大きく，ハンドアイ自体の慣性が小さいことが影響していると考えられ る. (a.2)では, $\Delta x_{M G}$ は微小で $\Delta x_{E d E}$ が $\pm 80[\mathrm{~mm}]$ 程度振動している.したがって， $\mathrm{T}=20[\mathrm{~s}]$ ですでにハンド部 $\vec{\Sigma}_{E}$ 


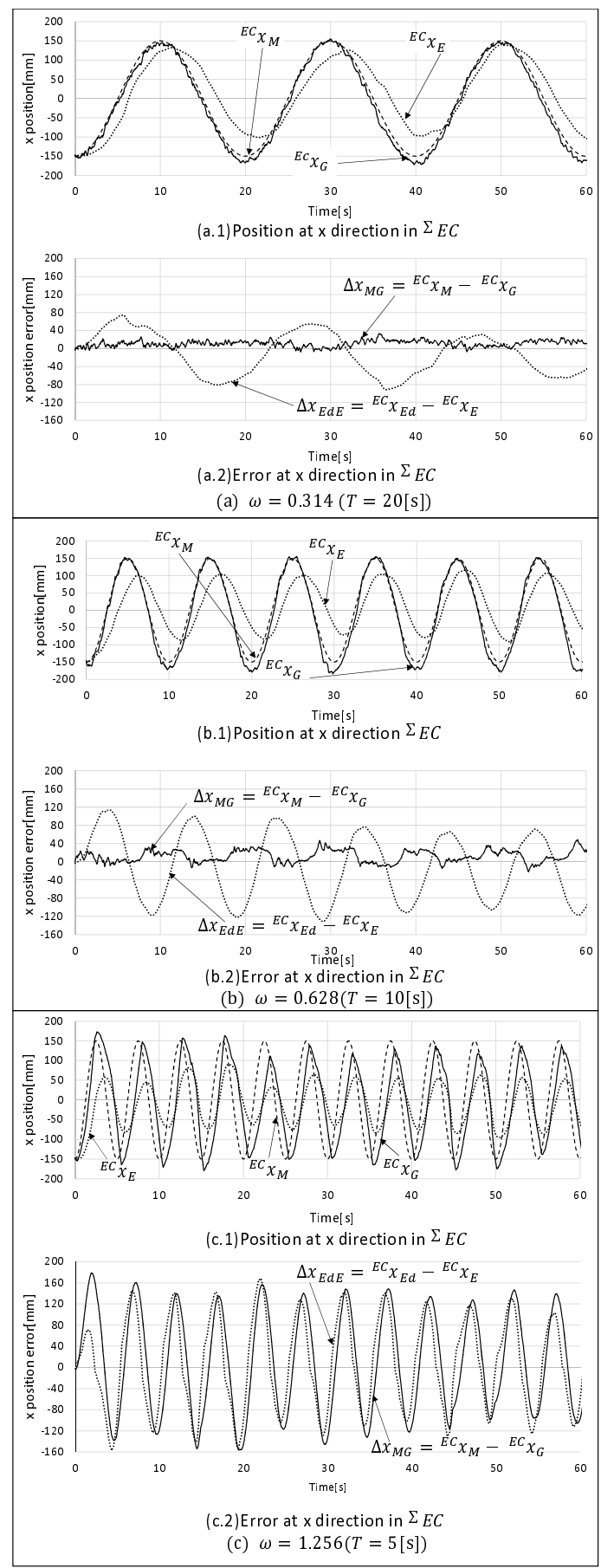

Fig. 17 Movements of target ${ }^{E C} x_{M}$, end effector ${ }^{E C} x_{E}$ and gazing point ${ }^{E C} x_{G}$ on the x-axis direction in the center coordinate system of hand $\Sigma_{E C}$. On condition that the object's pose $\mathrm{x}, \mathrm{y}, \mathrm{z}, \varepsilon_{1}, \varepsilon_{2}$ and $\varepsilon_{3}$ are recognized Multi-step GA. Refer to Eq.(23) and Eq.(25) for the related symbols in the figure.

は遅れているが, gazing point は遅れていない . (b.2)の $\mathrm{T}=10[\mathrm{~s}]$ の条件では, $\Delta x_{M G}$ に振動が現れるが $\Delta x_{E d E}$ の振幅 はさらに増大し， $\pm 110[\mathrm{~mm}]$ に達している . (a.2)，(b.2)より Eye-vergence の効果を理解することができる . (c.2)， $\mathrm{T}=5[\mathrm{~s}]$ では $\Delta x_{M G}, \Delta x_{E d E}$ とも増大してあり，Gazing point も 3D マーカーを追跡できていないことが分かる .

4.4.5 追従実験の姿勢追従結果と分析

図 18 , 図 19 と図 20 の三つの図は図 16 の実験中に得た手先と認識した対象物の姿勢データであり，3.4 節に紹 介したクォータニオンで表示した応答曲線である.したがって, 認識した対象物の姿勢 $\boldsymbol{\varepsilon}_{\widehat{M}}=\left[\varepsilon_{\widehat{M} 1}, \varepsilon_{\widehat{M} 2}, \varepsilon_{\widehat{M} 3}\right]^{T}$ と手 先の姿勢 $\boldsymbol{\varepsilon}_{E}=\left[\varepsilon_{E 1}, \varepsilon_{E 2}, \varepsilon_{E 3}\right]^{T}$ につて，図 18 は $\varepsilon_{\widehat{M} 1}$ と $\varepsilon_{E 1}$ を調べた結果であり，図 19 は $\varepsilon_{\widehat{M} 2}$ と $\varepsilon_{E 2}$, 図 20 は $\varepsilon_{\widehat{M} 3}$ と $\varepsilon_{E 3}$ の結果である . 対象物は回転しないため, 式 (22)に示すように対象物の実際の姿勢 ${ }^{E C} \boldsymbol{\varepsilon}_{M}=\mathbf{0}$ ，また手先の 


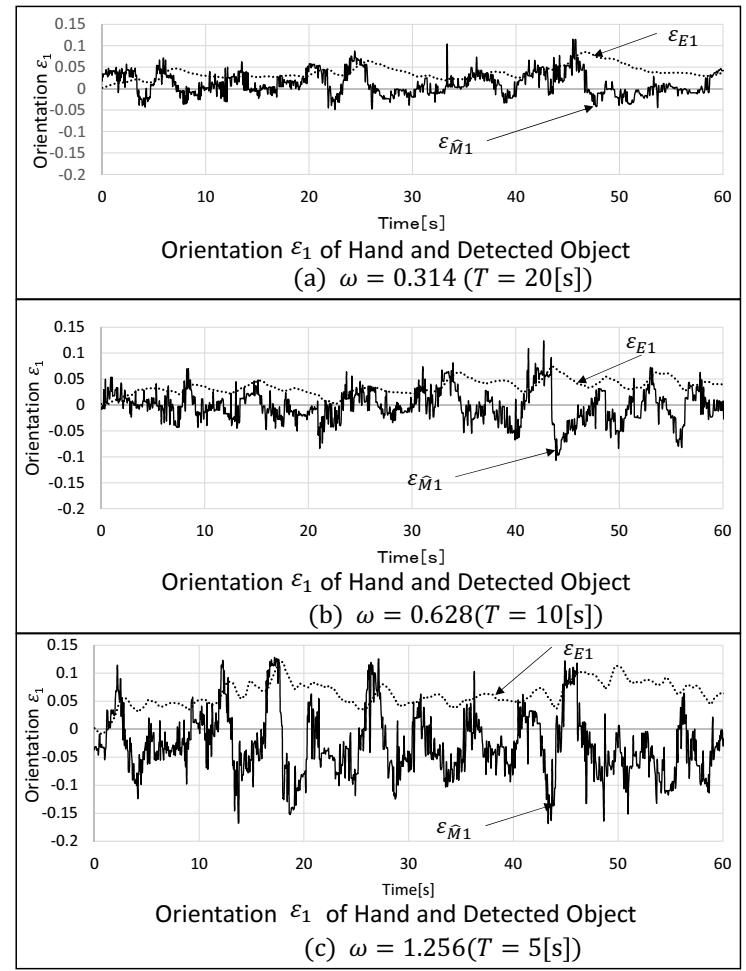

Fig. 18 Changes of orientation $\varepsilon_{1}$ of hand and detected object during tracking movement. Target values are ${ }^{E C} \varepsilon_{E 1}=0$ and ${ }^{E C} \varepsilon_{M 1}=0$ respectively.

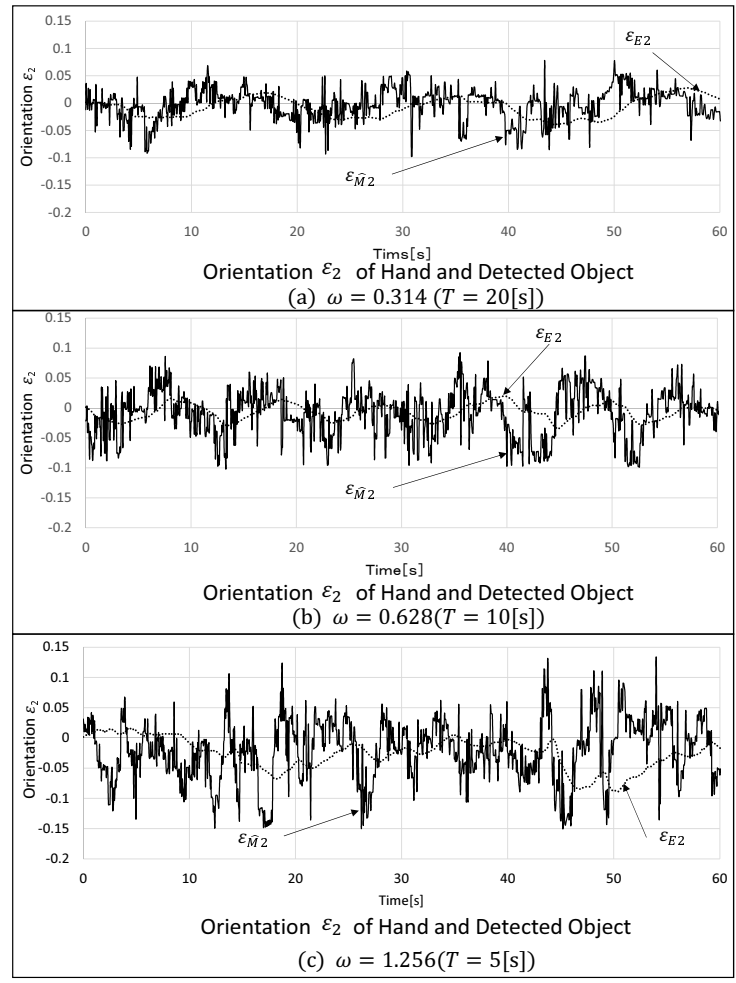

Fig. 19 Changes of orientation $\varepsilon_{2}$ of hand and detected object during tracking movement. Target values are ${ }^{E C} \varepsilon_{E 2}=0$ and ${ }^{E C} \varepsilon_{M 2}=0$ respectively.

目標姿勢 ${ }^{E C} \boldsymbol{\varepsilon}_{E d}=\mathbf{0}$ である . 弚の故，すべての応答曲線は同時に追跡及ひ認識の誤差を表す．

図 18 は認識した対象物の $\Sigma_{E C}$ の $\mathrm{x}$ 軸回りの姿勢 $\varepsilon_{\widehat{M} 1}$ と手先の姿勢 $\varepsilon_{E 1}$ の応答を表す . 各周波数に対して認識し た結果 $\varepsilon_{\widehat{M} 1}$ は急峻に変動しているが, 目標値である 0 付近を中心として変化している. 三つの図を互いに比べる と, 認識の結果 $\varepsilon_{\widehat{M} 1}$ は周波数の増加と共に, 誤差が大きくなることが分かる．したがって, 認識結果によって手 


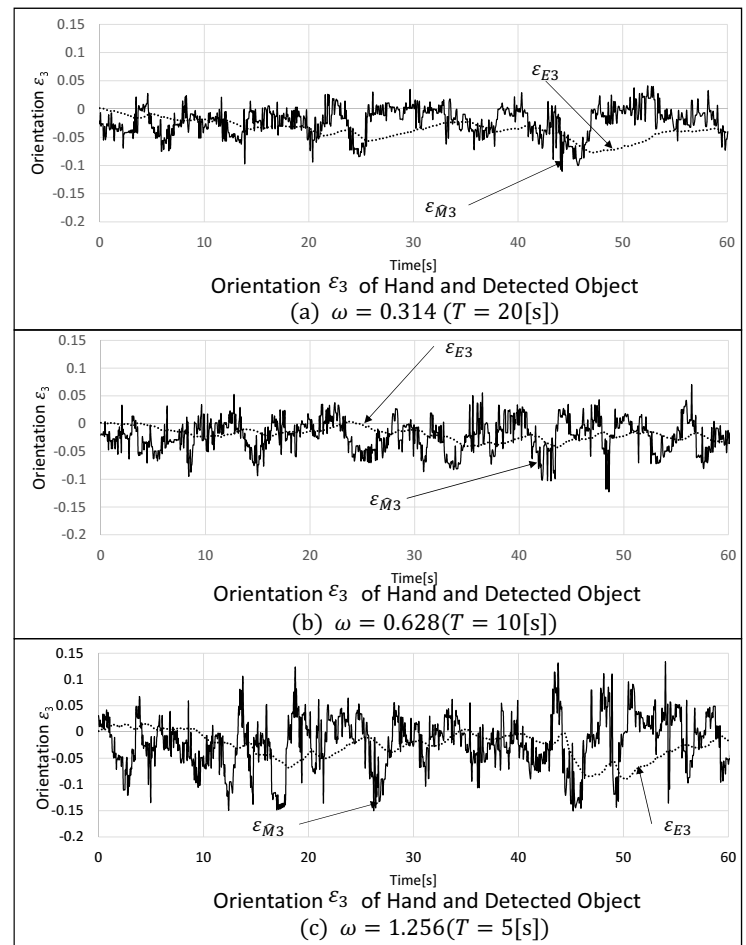

Fig. 20 Changes of orientation $\varepsilon_{3}$ of hand and detected object during tracking movement. Target values are ${ }^{E C} \varepsilon_{E 3}=0$ and ${ }^{E C} \varepsilon_{M 3}=0$ respectively.

先の誤差も増加する .

図 19 は認識した対象物の $\Sigma_{E C}$ の $\mathrm{y}$ 軸回りの姿勢 $\varepsilon_{\widehat{M} 2}$ と手先の姿勢 $\varepsilon_{E 2}$ の応答を表す . (a) , (b) , (c) は $\mathrm{T}=20 ， 10$ ， $5[\mathrm{~s}]$ と条件か変化しており， $\varepsilon_{E 2} ， \varepsilon_{\widehat{M} 2}$ は乥れ光れ周期 $20 ， 10 ， 5[\mathrm{~s}]$ の振動を含んでいる.これは， $\Sigma_{E C}$ の $\mathrm{x}$ 軸方 向の周期運動が $\mathrm{y}$ 軸方向の姿勢に影響していることを示している . マニピュレータのハンド部 $\vec{\Sigma}_{E}$ の運動は ${ }^{E C} x$ の 方向に遅延があるため, Eye-vergence の機能としてカメラを $\vec{\Sigma}_{E}$ の $y_{E}$ 軸回りに回転させて注視する . この結果 $\mathrm{y}$ 軸回りの姿勢偏差が生じ $\varepsilon_{\widehat{M} 2}$ の誤差が誘起されると考えられる.

図 20 は認識した対象物の姿勢 $\varepsilon_{\widehat{M} 3}$ と手先の姿勢 $\varepsilon_{E 2}$ の z 軸回りの応答を表す . 図 18 と同じように , 各周波数に 対して認識した結果は細く振動している .この結果は, 実際のハンド部 $\vec{\Sigma}_{E}$ の振動を示すものではなく, Multi-Step GA の対象物付近の収束が振動を伴っていることを示している .

\section{5. 結言}

本研究では, 提案したビジュアルサーボシステムの有効性を確認するために, 移動対象物のビジュアルサーボ周 波数応答実機実験を行った . 特に Eye-vergence システムの特徵と対象物を視野内に捕え続けるトラッキング性能 について実験的に検証した . 3 次元マーカーを用いた複眼動画像計測によりビデオレート (30fps) でリアルタイム に計測される位置・姿勢 6 変数をフィードバックするビジュアルサーボ系を用いた実験により，Eye-Vergence シ ステムの追跡性がハンド部の追跡性より優れているという結論を得た。しかし，この結論が普遍性を持つかどう かについては，本報の実験のみで判断することは難しいと考える．どのような条件を満足すれば，普遍性を担保 できるかについて今後の議論を待ちたいと考える .

$$
\text { 文献 }
$$

Allen, P. K., Timcenko, A., Yoshimi, B. and Michelman, P., Automated tracking and grasping of a moving object with a robotic hand-eye system. IEEE Transactions on Robotics and Automation, Vol. 9, No.2 (1993), pp. 152-165.

Brandou, V., Malis, E., Rives, P., Allais, A. G. and Perrier, M., Active stereovision using invariant visual servoing. In Intelligent Robots and Systems, 2006 IEEE/RSJ International Conference (2006), pp. 2326-2331.

Chesi, G., Hashimoto, K., Prattichizzo, D. and Vicino, A., Keeping features in the field of view in eye-in-hand visual servoing: A switching approach. IEEE Transactions on Robotics, Vol.20, No.5 (2004), 908-914. 
Dune, C., Marchand, E. and Leroux, C., One click focus with eye-in-hand/eye-to-hand cooperation. In Robotics and Automation, 2007 IEEE International Conference (2007), pp. 2471-2476.

Furukawa, N., Namiki, A., Taku, S. and Ishikawa, M., Dynamic regrasping using a high-speed multifingered hand and a high-speed vision system, In Robotics and Automation, 2006. ICRA 2006, Proceedings 2006 IEEE International Conference (2006), pp. 181-187.

Hiramatsu, T., Fukao, T., Kurashiki, K. and Osuka, K., Image-based path following control of mobile robots with central catadioptric cameras. In Robotics and Automation, ICRA'09. IEEE International Conference (2009). pp. 4045-4050.

Hutchinson, S., Hager, G. D. and Corke, P. I., A tutorial on visual servo control, IEEE transactions on robotics and automation, Vol.12, No.5 (1996), pp. 651-670.

Kim, D. J., Lovelett, R. and Behal, A., Eye-in-hand stereo visual servoing of an assistive robot arm in unstructured environments. In Robotics and Automation, 2009. ICRA'09. IEEE International Conference (2009), pp. $2326-2331$.

寇ギョウ郡, 田宏志, 見浪護, Visual servoing to longitudinally moving object based on hand/eye-vergence dual cameras system, SICE 第 9 回 CI 研究会 (2016), pp. 16-22.

Kou, Y., Tian, H., Minami, M., Matsuno, T., Analyses of optimization performance in longitudinal pose tracking with eye-vergence system, 22st International Symposium on Artificial Life and Robotics (2017), B-Con Plaza Beppu, pp. 19-21.

Maeda, K., Minami, M., Yanou, A., Matsumoto, H., Yu, F. and Hou, S., Frequency response experiments of 3-d pose fulltracking visual servoing with eye-vergence hand-eye robot system, Proceedings of SICE Annual Conference (SICE) (2012), pp. 101-107.

Malis, E., Chaumette, F. and Boudet, S., 2 1/2 D visual servoing, IEEE Transactions on Robotics and Automation, Vol.15, No.2 (1999), 238-250.

Massoud Farahmand, A., Shademan, A., Jagersand, M. and Szepesvári, C., Model-based and model-free reinforcement learning for visual servoing. In Robotics and Automation, 2009. ICRA'09. IEEE International Conference (2009), pp. 2917-2924.

松浦精太郎, 丸典明, 視空間誤差を用いた仮想バネダンパ仮説に基づくダイナミックビジュアルサーボによる EyeIn-Hand 型ロボットの位置姿勢制御，日本機械学会論文集 C 編 Vol.77, No.776, (2011), pp.186-195.

Minami, M. and Song, W., Hand-eye motion-invariant pose estimation with online 1-step GA-3D pose tracking accuracy evaluation in dynamic hand-eye oscillation. Journal of Robotics and Mechatronics, Vol.21, No.6 (2009), pp.709-719.

見浪護, 西村健太, 須浪唯介, 矢納陽, 崔禹, 山下学, 石山新太郎,3 次元複眼立体認識を用いた除染ロボットの提案と 精度検証実験, 日本機械学会論文集 , Vol.81, No. 831 (2015), DOI: 10.1299/transjsme.15-00216.

Natale, C., Interaction control of robot manipulators: six degrees-of-freedom tasks, Springer Science \& Business Media, Vol. 3 (2003).

Oh, P. Y. and Allen, K., Visual servoing by partitioning degrees of freedom, IEEE Transactions on Robotics and Automation, Vol.17, No.1 (2001), pp. 1-17.

奥村光平, 石井将人, 巽瑛理, 奥寛雅, 石川正俊, 高速視線制御光学系による高速飛翔体の映像計測, 計測自動制御学 会論文集 , Vol.49, No.9 (2013), pp.855-864.

Oonishi, S., Yanou, A. and Minami, M., Human-face-tracking using visual servoing by patient robot, Proceedings of SICE Annual Conference (2013), pp. 2266-2271.

Phyu, K. W., Funakubo R., Hagiwara, R., Tian, H. and Minami, M., Verification of illumination tolerance for photomodel-based cloth recognition. Artificial Life and Robotics (2017), pp. 1-13.

Sepp, W., Fuchs, S. and Hirzinger, G., Hierarchical featureless tracking for position-based 6-dof visual servoing. In Intelligent Robots and Systems, 2006 IEEE/RSJ International Conference (2006), pp. 4310-4315.

Shiozaki, T. and Murakami, T., Trackabilifty based motion control in mobile hand-eye system. In SICE-ICASE, International Joint Conference (2006), pp. 5304-5309.

Song, W., Minami, M., Mae, Y. and Aoyagi, S., On-line evolutionary head pose measurement by feedforward stereo model matching. In Robotics and Automation, 2007 IEEE International Conference (2007), pp.4394-4400.

Song, W. and Minami, M., Hand \& eye-vergence dual visual servoing to enhance observability and stability, In Robotics 
and Automation, 2009. ICRA’09, IEEE International Conference (2009), pp. 714-721.

宋薇, 見浪護, 青柳誠司, クォータニオンを用いたフィードフォワードオンラインポーズ遺伝的認識法, 日本ロボッ 卜学会誌, Vol.28, No.1 (2010), pp.55-64.

宋薇, 見浪護, フィードフォワード遺伝的認識法を用いた 3- D ビジュアルサーボ, 日本ロボット学会誌, Vol.28, No.5 (2010), pp.591-598.

Song, W., Yu, F. and Minami,M., 3D visual servoing by feedforward evolutionary recognition, Journal of Advanced Mechanical Design, Systems, and Manufacturing (JAMDSM) Vol.4, No.4 (2010), pp.739-755.

Song, W., Minami, M., Yu, F., Zhang, Y. and Yanou, A., 3-D hand \& eye-vergence approaching visual servoing with lyapunouv-stable pose tracking. In Robotics and Automation (ICRA), 2011 IEEE International Conference (2011), pp. 5210-5217.

Stavnitzky, J. and Capson, D., Multiple camera model-based 3-D visual servo, IEEE transactions on robotics and automation, Vol.16, No.6 (2000), pp.732-739.

Suzuki, H. and Minami, M., Visual servoing to catch fish using global/local GA search. IEEE/ASME Transactions on Mechatronics, Vol.10, No.3 (2005), pp.352-357.

Tahri, O., Mezouar, Y., Chaumette, F. and Corke, P., Generic decoupled image-based visual servoing for cameras obeying the unified projection model. In Robotics and Automation, 2009. ICRA'09. IEEE International Conference (2009), pp. 1116-1121.

Tahri, O. and Chaumette, F., Point-based and region-based image moments for visual servoing of planar objects, IEEE Transactions on Robotics, Vol.21, No.6 (2005), pp. 1116-1127.

\section{References}

Allen, P. K., Timcenko, A., Yoshimi, B. and Michelman, P., Automated tracking and grasping of a moving object with a robotic hand-eye system. IEEE Transactions on Robotics and Automation, Vol.9, No.2 (1993), pp. 152-165.

Brandou, V., Malis, E., Rives, P., Allais, A. G. and Perrier, M., Active stereovision using invariant visual servoing. In Intelligent Robots and Systems, 2006 IEEE/RSJ International Conference (2006), pp. 2326-2331.

Chesi, G., Hashimoto, K., Prattichizzo, D. and Vicino, A., Keeping features in the field of view in eye-in-hand visual servoing: A switching approach. IEEE Transactions on Robotics, Vol.20, No.5 (2004), 908-914.

Dune, C., Marchand, E. and Leroux, C., One click focus with eye-in-hand/eye-to-hand cooperation. In Robotics and Automation, 2007 IEEE International Conference (2007), pp. 2471-2476.

Furukawa, N., Namiki, A., Taku, S. and Ishikawa, M., Dynamic regrasping using a high-speed multifingered hand and a high-speed vision system, In Robotics and Automation, 2006. ICRA 2006, Proceedings 2006 IEEE International Conference (2006), pp. 181-187.

Hiramatsu, T., Fukao, T., Kurashiki, K. and Osuka, K., Image-based path following control of mobile robots with central catadioptric cameras. In Robotics and Automation, ICRA'09. IEEE International Conference (2009), pp. 4045-4050.

Hutchinson, S., Hager, G. D. and Corke, P. I., A tutorial on visual servo control, IEEE transactions on robotics and automation, Vol.12, No.5 (1996), pp. 651-670.

Kim, D. J., Lovelett, R. and Behal, A., Eye-in-hand stereo visual servoing of an assistive robot arm in unstructured environments. In Robotics and Automation, 2009. ICRA'09. IEEE International Conference (2009), pp. $2326-2331$.

Kou, Y., Tian, H. and Minami, M., Visual servoing to longitudinally moving object based on hand/eye-vergence dual cameras system, 9th SICE Symposium on Computational Intelligence (2016), pp. 16-22.

Kou, Y., Tian, H., Minami, M. and Matsuno, T., Analyses of optimization performance in longitudinal pose tracking with eye-vergence system, 22st International Symposium on Artificial Life and Robotics (2017), B-Con Plaza Beppu, pp. 19-21.

Maeda, K., Minami, M., Yanou, A., Matsumoto, H., Yu, F. and Hou, S., Frequency response experiments of 3-d pose full-tracking visual servoing with eye-vergence hand-eye robot system, In SICE Annual Conference (SICE) (2012), pp. 101-107. 
Malis, E., Chaumette, F. and Boudet, S., 2 1/2 D visual servoing, IEEE Transactions on Robotics and Automation, Vol. 15, No.2 (1999), 238-250.

Massoud Farahmand, A., Shademan, A., Jagersand, M. and Szepesvári, C., Model-based and model-free reinforcement learning for visual servoing. In Robotics and Automation, 2009. ICRA'09. IEEE International Conference (2009), pp. 2917-2924.

Matsuura, S. and Maru, N., Position and attitude control of eye-in-hand robot by dynamic visual servoing based on virtual spring-dumper hypothesis using binocular visual space error, Transactions of the Japan Society of Mechanical Engineers, Series C, Vol.77, No.776 (2011), pp.186-195 (in Japanese).

Minami, M. and Song, W. Hand-eye motion-invariant pose estimation with online 1-step GA-3D pose tracking accuracy evaluation in dynamic hand-eye oscillation. Journal of Robotics and Mechatronics, Vol.21, No.6 (2009), pp.709-719.

Minami, M., Nishimura, K., Sunami Y., Yanou, A., Cui, Y., Yamashita, M. and Ishiyama, S., A proposal of decontamination robot using 3D hand-eye-dual-cameras solid recognition and accuracy validation, Transactions of the JSME (in Japanese) (2015), Vol.81, No. 831, DOI: 10.1299/transjsme.15-00216.

Natale, C., Interaction control of robot manipulators: six degrees-of-freedom tasks, Springer Science \& Business Media, Vol. 3 (2003).

Oh, P. Y. and Allen, K., Visual servoing by partitioning degrees of freedom, IEEE Transactions on Robotics and Automation, Vol.17, No.1 (2001), pp. 1-17.

Okumura, K., Ishii, M., Tatsumi, E., Oku, H. and Ishikawa, M., Image measurement of a high-speed flying object using the high-speed gaze controller, Transactions of the Society of Instrument and Control Engineers, Vol. 49, No.9 (2013), pp.855-864, (in Japanese).

Oonishi, S., Yanou, A. and Minami, M., Human-face-tracking using visual servoing by patient robot. Proceedings of SICE Annual Conferenc (2013), pp. 2266-2271.

Phyu, K. W., Funakubo R., Hagiwara, R., Tian, H. and Minami, M., Verification of illumination tolerance for photomodel-based cloth recognition. Artificial Life and Robotics (2017), pp. 1-13.

Sepp, W., Fuchs, S. and Hirzinger, G., Hierarchical featureless tracking for position-based 6-dof visual servoing. In Intelligent Robots and Systems, 2006 IEEE/RSJ International Conference (2006), pp. 4310-4315.

Shiozaki, T. and Murakami, T., Trackabilifty based motion control in mobile hand-eye system. In SICE-ICASE, International Joint Conference (2006), pp. 5304-5309.

Song, W., Minami, M., Mae, Y. and Aoyagi, S, On-line evolutionary head pose measurement by feedforward stereo model matching. In Robotics and Automation, 2007 IEEE International Conference (2007), pp.4394-4400.

Song, W. and Minami, M., Hand \& eye-vergence dual visual servoing to enhance observability and stability, In Robotics and Automation, 2009. ICRA'09, IEEE International Conference (2009), pp.714-721.

Song, W., Minami, M. and Aoyagi, S., Feedforward on-line pose evolutionary recognition based on quaternion, Journal of the Robotics Society of Japan, Vol.28, No.1 (2010), pp.55-64,(in Japanese).

Song, W. and Mamoru M., 3-D visual servoing using feedforward evolutionary recognition, Journal of the Robotics Society of Japan, Vol.28, No.5 (2010), pp.591-598, (in Japanese).

Song, W., Yu, F. and Minami,M., 3D visual servoing by feedforward evolutionary recognition, Journal of Advanced Mechanical Design, Systems, and Manufacturing (JAMDSM), Vol.4, No.4 (2010), pp.739-755.

Song, W., Minami, M., Yu, F., Zhang, Y. and Yanou, A., 3-D hand \& eye-vergence approaching visual servoing with lyapunouv-stable pose tracking. In Robotics and Automation (ICRA), IEEE International Conference (2011), pp. 5210-5217.

Stavnitzky, J. and Capson, D., Multiple camera model-based 3-D visual servo, IEEE transactions on robotics and automation, Vol.16, No.6 (2000), pp.732-739.

Suzuki, H. and Minami, M., Visual servoing to catch fish using global/local GA search. IEEE/ASME Transactions on Mechatronics, Vol.10, No.3 (2005), pp.352-357.

Tahri, O., Mezouar, Y., Chaumette, F. and Corke, P., Generic decoupled image-based visual servoing for cameras obeying the unified projection model. In Robotics and Automation, 2009. ICRA'09. IEEE International Conference (2009), 
Tian, Kou and Minami, Transactions of the JSME (in Japanese), Vol.84, No.857 (2018)

pp. 1116-1121.

Tahri, O. and Chaumette, F., Point-based and region-based image moments for visual servoing of planar objects, IEEE Transactions on Robotics, Vol.21, No.6 (2005), pp. 1116-1127. 